\title{
Study of Overprotective-Polarization of Steel Subjected to Cathodic Protection in Unsaturated Soil
}

\author{
Mandlenkosi G. R. Mahlobo ${ }^{1}$, Peter A. Olubambi ${ }^{1}$, Phumlani Mjwana ${ }^{1}$, Marc Jeannin ${ }^{2}$ and Philippe Refait ${ }^{2, * \mathbb{D}}$ \\ 1 Centre for Nanoengineering and Tribocorrosion, University of Johannesburg, \\ Johannesburg 2028, South Africa; mahlobomgr@yahoo.com (M.G.R.M.); polubambi@uj.ac.za (P.A.O.); \\ mjwanap@gmail.com (P.M.) \\ 2 Laboratory of Engineering Sciences for the Environment (LaSIE)—UMR 7356, University of La \\ Rochelle/CNRS, 17000 La Rochelle, France; mjeannin@univ-lr.fr \\ * Correspondence: prefait@univ-lr.fr; Tel.: +33-5-4645-8227
}

Citation: Mahlobo, M.G.R.;

Olubambi, P.A.; Mjwana, P.; Jeannin,

M.; Refait, P. Study of

Overprotective-Polarization of Stee Subjected to Cathodic Protection in Unsaturated Soil. Materials 2021, 14 4123. https://doi.org/10.3390/ ma14154123

Academic Editor: Frank Czerwinski

Received: 28 June 2021

Accepted: 22 July 2021

Published: 24 July 2021

Publisher's Note: MDPI stays neutral with regard to jurisdictional claims in published maps and institutional affiliations.

Copyright: (c) 2021 by the authors. Licensee MDPI, Basel, Switzerland. This article is an open access article distributed under the terms and conditions of the Creative Commons Attribution (CC BY) license (https:// creativecommons.org/licenses/by/ $4.0 /)$.
Abstract: Various electrochemical methods were used to understand the behavior of steel buried in unsaturated artificial soil in the presence of cathodic protection (CP) applied at polarization levels corresponding to correct $\mathrm{CP}$ or overprotection. Carbon steel coupons were buried for 90 days, and the steel/electrolyte interface was studied at various exposure times. The coupons remained at open circuit potential (OCP) for the first seven days before $\mathrm{CP}$ was applied at potentials of -1.0 and $-1.2 \mathrm{~V}$ vs. $\mathrm{Cu} / \mathrm{CuSO}_{4}$ for the remaining 83 days. Voltammetry revealed that the corrosion rate decreased from $\sim 330 \mu \mathrm{m} \mathrm{yr}^{-1}$ at OCP to $\sim 7 \mu \mathrm{m} \mathrm{yr}^{-1}$ for an applied potential of $-1.0 \mathrm{~V}$ vs. $\mathrm{Cu} / \mathrm{CuSO}_{4}$. CP effectiveness increased with time due to the formation of a protective layer on the steel surface. Raman spectroscopy revealed that this layer mainly consisted of magnetite. EIS confirmed the progressive increase of the protective ability of the magnetite-rich layer. At $-1.2 \mathrm{~V}$ vs. $\mathrm{Cu} / \mathrm{CuSO}_{4}$, the residual corrosion rate of steel fluctuated between 8 and $15 \mu \mathrm{m} \mathrm{yr}^{-1}$. EIS indicated that the protective ability of the magnetite-rich layer deteriorated after day 63. As water reduction proved significant at this potential, it is proposed that the released $\mathrm{H}_{2}$ bubbles damage the protective layer.

Keywords: cathodic protection; carbon steel; polarization level; EIS; voltammetry; unsaturated soil

\section{Introduction}

Buried carbon steel is very susceptible to corrosion when exposed to soil environments [1-12]. Underground pipelines must then be protected from external corrosion, which is achieved using the combination of organic coatings and cathodic protection (CP). Common coatings used on pipelines, past or present, are high build epoxy, coal tar, polyethylene, polyolefin and polyurethane [13]. Combined with a coating, CP protects the parts of the pipeline surface that are in contact with the soil because the coating is damaged or defective. Standards such as NF EN 12954 and NF EN ISO 15589-1 [14,15] specify the protection potential to be applied to achieve an efficient cathodic protection, i.e., to ensure a "residual" corrosion rate (that is the corrosion rate achieved with CP) lower or equal to $10 \mu \mathrm{m} \mathrm{yr}^{-1}$. According to the NF EN 12954 standard, the potential required for the protection of steel buried in aerated unsaturated soils is, in most cases, $-0.85 \mathrm{~V}$ vs. $\mathrm{Cu} / \mathrm{CuSO}_{4}$. At such potential, in aerated conditions, the main cathodic process is the reduction of dissolved oxygen:

$$
\mathrm{O}_{2}+2 \mathrm{H}_{2} \mathrm{O}+4 \mathrm{e}^{-} \rightarrow 4 \mathrm{OH}^{-}
$$

This potential value is, however, only a threshold and a further decrease of the potential would in principle lead to a further decrease of the residual corrosion rate. For 
instance, at $-1.0 \mathrm{~V}$ vs. $\mathrm{Cu} / \mathrm{CuSO}_{4}, \mathrm{CP}$ is expected to be more efficient. At lower potentials, the reduction of $\mathrm{H}_{2} \mathrm{O}$, i.e., the hydrogen evolution reaction (HER), may also take place:

$$
2 \mathrm{H}_{2} \mathrm{O}+2 \mathrm{e}^{-} \rightarrow \mathrm{H}_{2}+2 \mathrm{OH}^{-}
$$

The production of $\mathrm{OH}^{-}$ions by the cathodic reactions (1) and/or (2) induces an increase of the interfacial $\mathrm{pH}$ that may lead to the formation of a calcareous deposit [16-18] on the steel surface or even promote the passivation of the metal surface [19] or the formation of a protective oxide layer [20]. In the field, the aimed applied potential is lower than the threshold of $-0.85 \mathrm{~V}$ vs. $\mathrm{Cu} / \mathrm{CuSO}_{4}$, typically about -0.95 to $-1.0 \mathrm{~V}$ vs. $\mathrm{Cu} / \mathrm{CuSO}_{4}$. Significantly lower potentials, e.g., as $-1.2 \mathrm{~V}$ vs. $\mathrm{Cu} / \mathrm{CuSO}$, are avoided because a high cathodic rate associated with intense water reduction leads to a very high interfacial $\mathrm{pH}$. This can be detrimental for the coating associated with $\mathrm{CP}$ to protect the metal from corrosion (as recalled in the corresponding standard [14]) because it can generate a delamination process.

Previous studies were devoted to the effectiveness of cathodic protection (CP) of buried steel structures and/or to its failure mechanisms under different soil conditions [21,22]. Various factors were reported to have a significant influence towards $\mathrm{CP}$ effectiveness, in particular those affecting the transport of crucial components $\left(\mathrm{O}_{2}, \mathrm{OH}^{-}\right.$, etc.). Such factors are, for instance, the coating defect size and the properties of the environment surrounding the protected object [21,22]. CP modifies the chemical environment of the metal, mostly because of the accelerated cathodic processes [21,22]. Consequently, the kinetics and mechanism of the metal surface corrosion change, and all these changes depend on the applied cathodic potential. It proved necessary to determine the residual corrosion rate of the buried carbon steel in different kinds of soil that would, in turn, quantify the CP effectiveness and its link with the applied potential. Barbalat et al. [23,24] developed a method based on voltammetry to estimate the instantaneous residual corrosion rate of carbon steel in soil in the presence of CP. The methodology was optimized afterwards using a computer-fitting procedure of the polarization curves achieved using electrochemical laws $[25,26]$.

Besides, results obtained with electrochemical impedance spectroscopy (EIS) demonstrated that in unsaturated soils (about 35-65\% saturation) CP could lead to an increase of the active (or "wet") area $[25,26]$, a phenomenon more likely due to electrocapillary effects. In an unsaturated soil, the "wet" area is the part of the steel surface in contact with the soil electrolyte. The rest of the surface, which is in contact with air, does not participate in the electrochemical processes. More recently, the combined effects of cathodic polarization and variations of soil humidity were studied and it was shown that these effects depended on the applied potential [27]. It was also observed that the residual corrosion process led to a porous magnetite layer that influenced the cathodic reaction [27].

In some cases, the decrease of the potential indeed led to a decrease of the residual corrosion rate [20,27]. In other cases, an opposite effect was observed, suggesting that an excessively cathodic potential could be detrimental, more likely by hindering the formation of a protective layer of (residual) corrosion products [24,25].

The present study was then designed to monitor, using voltammetry and EIS, the evolution of the steel/electrolyte interface during "excessive" and "normal" CP in an unsaturated soil. More precisely, the main aim was to compare the protective ability of the mineral layer forming on the steel surface in both situations. For that purpose, steel coupons were buried in an artificial unsaturated soil for 90 days. They were left at open circuit potential (OCP) for the first seven days before $\mathrm{CP}$ was applied for the remaining 83 days of the experiment. EIS measurements were performed to study the evolution of the steel/electrolyte interface, while voltammetry was used to determine the residual corrosion rate using the methodology developed in previous works [25-27]. The characterization of the mineral layer covering the coupons at the end of the 90-day experiment was achieved by $\mu$-Raman spectroscopy. 


\section{Materials and Methods}

\subsection{Preparation of Steel Coupons}

This study made use of carbon steel S235JR as the testing material because it is commonly used for gas pipeline transportation system [28]. The nominal chemical composition of this material is (in wt.\%): C: $0.17 \%$ max., Mn: $1.40 \%$ max., P: $0.035 \%$ max., Cu: $0.55 \%$ $\max , \mathrm{N}: 0.012 \%$ max., and Fe for the rest. Cylindrical coupons of diameter $30 \mathrm{~mm}$ and $2 \mathrm{~mm}$ thickness were cut from the same carbon steel rod. The cut carbon steel coupons were connected to a copper wire and embedded in resin. The carbon steel coupons were mechanically prepared through grinding at 80 to 600 grits (grain size $26 \mu \mathrm{m}$ ). After grinding, the coupons were rinsed thoroughly with Milli-Q water and dried rapidly with a hairdryer. Only one circular side of the coupon (corresponding to the surface area of $7.07 \mathrm{~cm}^{2}$ ) was exposed to the soil environment.

\subsection{Soil Preparation and Electrochemical Cell Set Up}

This study made use of an artificial soil composed of $83 \mathrm{wt} . \%$ fine sand $\left(\mathrm{SiO}_{2}\right)$ particles (average particle size $22 \mu \mathrm{m}$ ), $14.5 \mathrm{wt} . \%$ clay (kaolinite) and $2.5 \mathrm{wt} . \%$ peat. The soil environment used for all the experiments was prepared by incorporating and mixing the electrolyte solution and the artificial soil to achieve $~ 65 \%$ soil saturation level ( $65 \%$ sat.). The selection of the electrolyte shown in Table 1 was mainly based on trying to achieve the solution with species commonly present in soil, particularly $\mathrm{Ca}^{2+}$ and $\mathrm{Mg}^{2+}$, which may play a role during cathodic protection, e.g., by inducing the formation of a calcareous deposit. The resulting $\mathrm{pH}$, once soil and electrolyte were mixed, was measured at 7.1 \pm 0.1 . All experiments were performed at room temperature $\left(21 \pm 2^{\circ} \mathrm{C}\right)$.

Table 1. Chemical composition of the electrolyte solution.

\begin{tabular}{lccccc}
\hline Compound & $\mathrm{NaCl}$ & $\mathrm{CaCl}_{2} 2 \mathrm{H}_{2} \mathrm{O}$ & $\mathrm{MgCl}_{6} \mathbf{6} \mathbf{H}_{2} \mathrm{O}$ & $\mathbf{N a S O}_{4} 7 \mathrm{H}_{2} \mathrm{O}$ & $\mathbf{N a H C O}_{3}$ \\
\hline Conc. $(\mathrm{g} / \mathrm{L})$ & 0.5844 & 0.2940 & 0.2033 & 0.4022 & 0.1680 \\
\hline
\end{tabular}

A $19 \mathrm{~cm} \times 25 \mathrm{~cm}$ Plexiglas cell (Figure 1) was used to bury two coupons inside the prepared soil, ensuring that they were as far apart from each other as possible. The soil was filled up to about $5-6 \mathrm{~cm}$ below the top of the cell to allow the remaining space for air (i.e., $\mathrm{O}_{2}$ ) into the system. The cell was closed with a lid to maintain constant soil moisture. The prepared steel coupons were used as working electrodes. The reference electrode was the Celco 5 (COREXCO, Décines Charpieu, France) copper-copper sulfate $\left(\mathrm{Cu} / \mathrm{CuSO}_{4}\right)$ electrode $\left(+0.316 \mathrm{~V} / \mathrm{SHE}\right.$ at $\left.25^{\circ} \mathrm{C}\right)$ specifically designed for soil experiments and commonly used in the field. It was also used in previous studies [10,11,23-27]. All electrochemical potentials were expressed with reference to this electrode, i.e., $\mathrm{V}$ vs. $\mathrm{Cu} / \mathrm{CuSO}$. A titanium grid, placed approximately at the center of the cell, was used as a counter electrode. Soil moisture was controlled during the experiment with a Waterscout SM100 sensor (Spectrum Technologies Inc., Aurora, IL, USA). It proved constant at $63 \pm 3 \%$ sat.

The two carbon steel coupons, denoted as $\mathrm{WE}_{\mathrm{CP} 1}$ and $\mathrm{WE}_{\mathrm{CP} 2}$, were buried in soil for 90 days. They were left at OCP for the first 7 days of the experiment. This duration was assumed sufficient for the system to reach a steady state, and the corrosion rate was then estimated by electrochemical measurements at day $7 . \mathrm{CP}$ was subsequently applied on the coupons for the remaining 83 days of the experiment. 

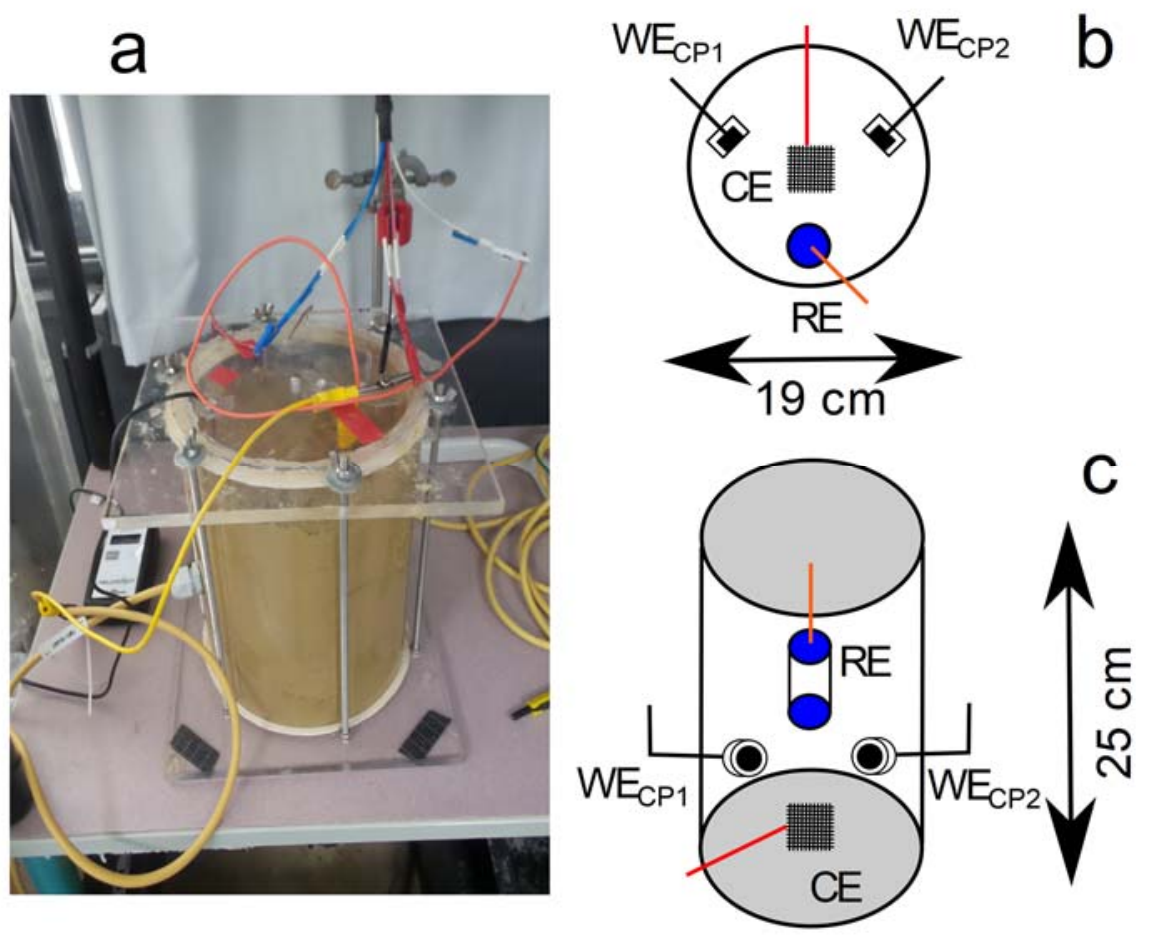

Figure 1. Representation of electrochemical cell for corrosion studies in soil: (a) picture of the cell, (b) schematic top view and (c) schematic side view. $\mathrm{CE}=$ counter electrode, $\mathrm{RE}=$ reference electrode, $\mathrm{WE}_{\mathrm{CP} 1}=$ working electrode cathodic protection 1 (steel coupon 1 ) and $\mathrm{WE}_{\mathrm{CP} 2}=$ working electrode cathodic protection 2 (steel coupon 2). The moisture sensor was omitted for clarity; the sensor reader is visible on the left of the picture.

\subsection{Electrochemistry}

\subsubsection{Cathodic Protection}

After the first 7 days at $\mathrm{OCP}, \mathrm{CP}$ was applied on coupons $\mathrm{WE}_{\mathrm{CP} 1}$ and $\mathrm{WE}_{\mathrm{CP} 2}$ at potential values, corrected from ohmic drop, $E_{\mathrm{CP}}=-1.0$ and $-1.2 \mathrm{~V}$ vs. $\mathrm{Cu} / \mathrm{CuSO}_{4}$, respectively. EIS measurements (see next section) were performed at 24-h time intervals to determine the soil electrolyte resistance $R_{\mathrm{S}}$. The applied potential was then corrected from ohmic drop according to the expression:

$$
E_{\mathrm{CP}}=E_{\mathrm{IRfree}}=E_{\mathrm{on}}-R_{\mathrm{s}} \cdot I
$$

where $E_{\text {IRfree }}$ is the corrected potential, $E_{\mathrm{on}}$ is the applied potential, $R_{\mathrm{S}}$ is the soil electrolyte resistance and $I$ is the current flowing through the electrode. Because I may vary with time, $E_{C P}$ may also vary until another correction is made (next day).

\subsubsection{Electrochemical Impedance Spectroscopy (EIS) Experiments}

All electrochemical measurements were performed in the cell displayed in Figure 1 using Gamry Interface 1000 potentiostats (Gamry Instruments, Warminster, PA, USA) monitored by the Framework software (V4.35, Gamry Instruments, Warminster, PA, USA). The results obtained were analyzed with the Gamry Echem Analyst software (V6.31, Gamry Instruments, Warminster, PA, USA). Electrochemical impedance spectroscopy (EIS) measurements were performed at a frequency between $100 \mathrm{kHz}$ and $200 \mathrm{mHz}$, and the AC voltage perturbation amplitude (peak to peak) was $0.03 \mathrm{~V}$ around the applied protection potential of the sample (for coupons under $\mathrm{CP}$ ) or around OCP (before the CP was applied). This high amplitude was required because of the important ohmic drop due to soil resistivity. The linearity of the system was checked in varying the amplitude of the AC signal applied to the sample. 
The soil electrolyte resistance $R_{\mathrm{S}}$ can be determined by EIS. It corresponds to the real part of the impedance when the frequency tends towards infinite. It must be noted that $R_{\mathrm{S}}$ is mainly linked, in unsaturated soils, to the "wet" area of the electrode $[10,11,25,26]$, i.e., the area really in contact with the electrolyte present in the pores of the soil. More precisely, $R_{\mathrm{S}}$ varies inversely to the wet area and, for instance, if the soil dries, i.e., the amount of electrolyte present in the pores decreases, then the wet area decreases and $R_{\mathrm{S}}$ increases. The value of $R_{\mathrm{S}}$ can then indicate if soil moisture varies at the vicinity of the coupon [11].

Actually, important variations of $R_{\mathrm{s}}$ were observed between day 7 (beginning of $\mathrm{CP}$ ) and day 42. This rather corresponds to a transition period between steady state OCP conditions and steady state CP conditions (this is discussed in Section 3.1). For this reason, it was decided to focus the present work on the characterization of the system after day 42 .

\subsubsection{Voltammetry Experiments}

For the coupons at OCP during the 7 first days, the polarization curves were recorded at a scan rate $(\mathrm{d} E / \mathrm{d} t)$ of $0.2 \mathrm{mV} / \mathrm{s}$ from OCP up to $+0.08 \mathrm{~V}$ and down to $-0.08 \mathrm{~V}$, i.e., on a limited range of potential so that the steel surface was only moderately affected. This method was used previously and referred to as "VAOCP" for "voltammetry around OCP" $^{\prime \prime}[10,29]$. It implies that the voltammograms obtained are mathematically modeled using electrochemical kinetic laws, which was achieved using the OriginPro 2016 Software (SR0 b9.3.226, OriginLab Corporation, Northampton, MA, USA). Electrochemical parameters such as anodic and cathodic Tafel coefficients are then obtained together with the corrosion current density $j_{\text {corr }}$. The corrosion rate $\tau_{\text {corr }}$ is then computed from $j_{\text {corr }}$ using Faraday's law.

For coupons under $\mathrm{CP}$, the polarization curves were recorded from the applied potential $E_{\mathrm{CP}}$ up to (approximately) $\mathrm{OCP}+0.08 \mathrm{~V}$, with $\mathrm{d} E / \mathrm{d} t=0.2 \mathrm{mV} / \mathrm{s}$. They were modelled as described elsewhere [25,26,29], and as also detailed further in the text (Section 3.2), to estimate $\tau_{\mathrm{rc}}$, the "residual" corrosion rate. $\tau_{\mathrm{rc}}$ is actually the corrosion rate associated with the anodic current density $j_{\mathrm{A}}$ at the applied potential $E_{\mathrm{CP}}[23-26]$, i.e., $j_{\mathrm{A}}\left(E_{\mathrm{CP}}\right)$. Because voltammetry may affect significantly the behavior of the system, the first polarization curves were acquired at day 42 , and only once a week afterwards, except at day 56, i.e., at days $49,63,70,77,84$ and 90. During the first 35 days of CP (from day 7 to day 42), i.e., during the transition period, the system was thus only subjected to minor perturbations, corresponding to EIS measurements.

\section{4. $\mu$-Raman Spectroscopy}

At the end of the experiment, the coupons were removed from the electrochemical cell with a part of soil covering their surface and kept inside a freezer where they were maintained at $-24^{\circ} \mathrm{C}$. This experimental procedure was used in previous works and proved adequate to preserve the system from further corrosion and evolution [30,31].

$\mu$-Raman spectroscopy analysis was performed at room temperature with a Jobin Yvon High Resolution Raman Spectrometer (LabRAM HR, Horiba, Tokyo, Japan) equipped with a microscope (Olympus BX 41, Olympus, Tokyo, Japan), a Peltier-based cooled charge coupled detector (CCD) and a He-Ne laser $(632.8 \mathrm{~nm})$. The laser power was kept at $10 \%$ of the maximum (i.e., $0.9 \mathrm{~mW}$ ) to prevent an excessive heating that can induce the transformation of the analyzed compounds into hematite $\left(\alpha-\mathrm{Fe}_{2} \mathrm{O}_{3}\right)$. The acquisition time was variable but equal to $60 \mathrm{~s}$ in most cases. It could be increased up to 5 min to optimize the signal to noise ratio. At least 20 zones (diameter of $\sim 6 \mu \mathrm{m}$ ) of each sample were analyzed through a $50 \times$ objective, with a resolution of $0.1 \mathrm{~cm}^{-1}$.

\section{Results}

\subsection{Electrochemical Impedance Spectroscopy}

EIS measurements were performed on both coupons at various exposure times in soil at OCP or under CP. In the present case dealing with a resistive medium, a parasitic influence of the reference electrode at high frequency was observed [32], and $R_{\mathrm{S}}$ was then 
determined at $10 \mathrm{kHz}$, i.e., $R_{\mathrm{s}}=\operatorname{Re}(\mathrm{Z})$ at $10 \mathrm{kHz}$. For the same reason the EIS data obtained at frequencies higher than $10 \mathrm{kHz}$ were not considered and are not shown on the Nyquist plots except when noted.

First, Figure 2 displays the evolution of $R_{\mathrm{S}}$ with time for coupons $\mathrm{WE}_{\mathrm{CP} 1}$ and $W E_{\mathrm{CP} 2}$ in soil during the whole experiment. During the OCP period (days 1-7), $R_{\mathrm{S}}$ increases from 1670 to $1865 \Omega \mathrm{cm}^{2}$ for coupon $W E_{\mathrm{CP} 1}$ and from 1380 to $1815 \Omega \mathrm{cm}^{2}$ for coupon $W E_{\mathrm{CP} 2}$. This increase in $R_{\mathrm{S}}$ can be attributed to the changes in soil physicochemical properties. Actually, water tends to flow vertically in the cell, because of gravity, so that a gradient of soil moisture appears with time. This movement of fluid necessarily modifies the soil at the vicinity of the coupons during the first days. Moreover, corrosion products are formed on the metal surface, which also modifies the steel/soil interface.

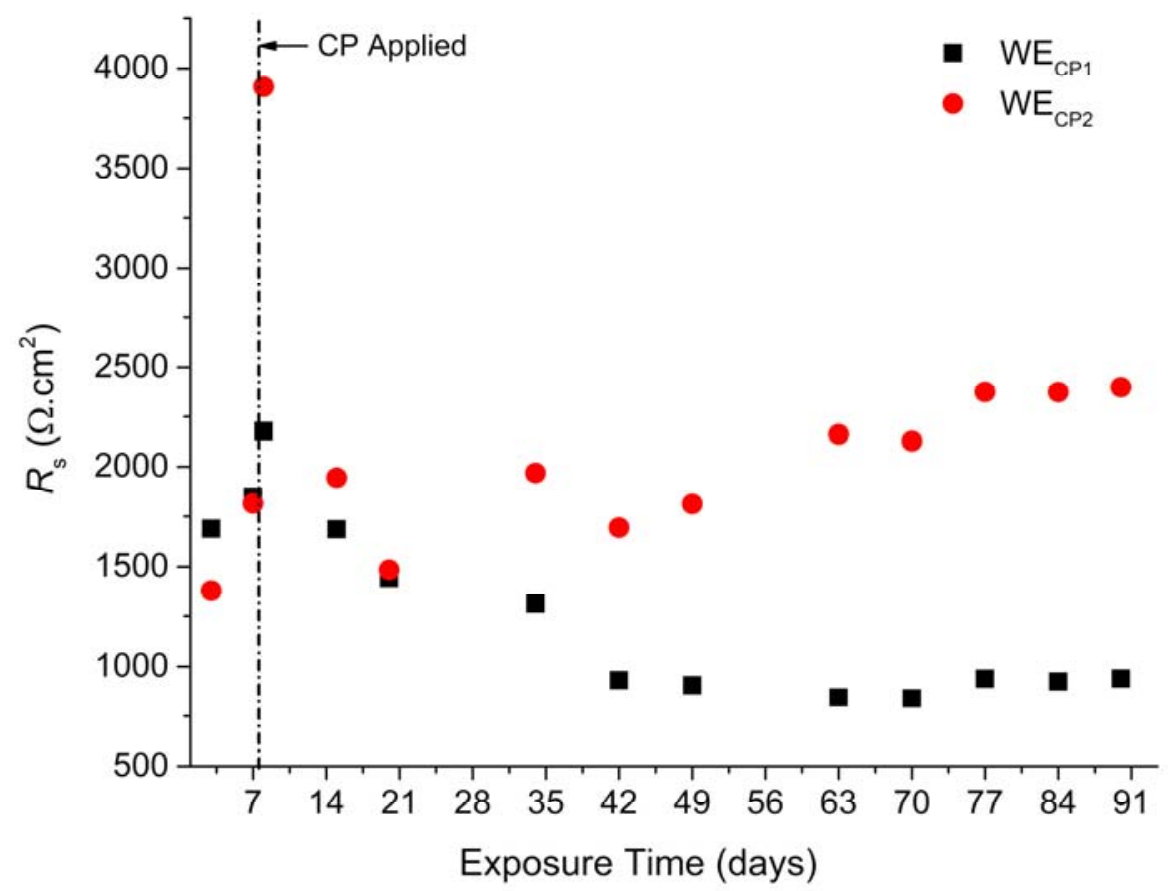

Figure 2. $R_{\mathrm{S}}$ evolution with exposure time for coupons $\mathrm{WE}_{\mathrm{CP} 1}$ and $\mathrm{WE}_{\mathrm{CP} 2}$.

The application of CP leads to an immediate sharp increase in $R_{\mathrm{S}}$ to $\sim 2250 \Omega \mathrm{cm}^{2}$ for coupon $\mathrm{WE}_{\mathrm{CP} 1}$ and $\sim 3850 \Omega \mathrm{cm}^{2}$ for coupon $\mathrm{WE}_{\mathrm{CP} 2}$. Various changes occur at the steel/electrolyte interface when $\mathrm{CP}$ is applied: dissolved $\mathrm{O}_{2}$ is consumed and interfacial $\mathrm{pH}$ increases, the electric field induces migration of ions, electrocapillary effects modify the contact angle between liquid phase and metal, etc. It is worth noticing that there is a difference of $1600 \Omega \mathrm{cm}^{2}$ in $R_{\mathrm{S}}$ values obtained between coupons WE $\mathrm{EP}_{\mathrm{CP}}$ and WE $\mathrm{E}_{\mathrm{CP} 2}$ after 8 days. This difference can then be attributed to the different applied $E_{\mathrm{CP}}$ values set for coupons $\mathrm{WE}_{\mathrm{CP} 1}$ and $\mathrm{WE}_{\mathrm{CP} 2}$, i.e., -1.0 and $-1.2 \mathrm{~V}$ vs. $\mathrm{Cu} / \mathrm{CuSO}_{4}$, respectively. This indicates that lower $E_{\mathrm{CP}}$ leads to higher $R_{\mathrm{S}}$. This initial increase of $R_{\mathrm{S}}$ is, however, followed by a rapid decrease so that at day 14 both $R_{\mathrm{S}}$ values are similar to those measured at OCP. This initial increase of $R_{\mathrm{S}}$ is then a transient phenomenon that was not further studied and is yet to be explained.

However, clear trends are observed after day 21. For coupon $\mathrm{WE}_{\mathrm{CP} 1}, R_{\mathrm{S}}$ decreases further before reaching a constant value of $890 \pm 50 \Omega \mathrm{cm}^{2}$ after day 42, indicating that a steady state has been reached. This value is actually $\sim 800 \Omega \mathrm{cm}^{2}$ lower than the initial value of $1670 \Omega \mathrm{cm}^{2}$ (day 3). This result is consistent with previous study [25], where the decrease of $R_{\mathrm{s}}$ was attributed to an increase of the "wet area" due to electrocapillary effects. A negative shift of potential allows the liquid phase to spread over the steel surface because it decreases the solid-liquid contact angle $\theta$ [33-36]. 
In contrast, $R_{\mathrm{S}}$ values obtained for coupon $\mathrm{WE}_{\mathrm{CP} 2}$ after 21 days take an opposite trend in relation to that observed for coupon $\mathrm{WE}_{\mathrm{CP} 1}$, i.e., increase again with exposure time. This increase is not continuous, and some fluctuations are observed, with local minima at days 42 and 70. $R_{\mathrm{s}}$ reaches a final value of $\sim 2400 \Omega \mathrm{cm}^{2}$ after 90 days, thus being $\sim 1000 \Omega \mathrm{cm}^{2}$ higher than the initial value of $1380 \Omega \mathrm{cm}^{2}$ (day 3). At the CP potential of $-1.2 \mathrm{~V}$ vs. $\mathrm{Cu} / \mathrm{CuSO}_{4}$, the cathodic process is enhanced, leading to the acceleration of $\mathrm{O}_{2}$ consumption at the steel/electrolyte interface and more likely to the increase of water reduction rate. The increase of $R_{\mathrm{S}}$ with time may then be due to the accumulation of hydrogen $\left(\mathrm{H}_{2}\right)$ bubbles that form on the steel surface according to Equation (2). This phenomenon would indeed lead to a decrease of the "wet" area (i.e., the area in contact with the liquid phase) and thus to an apparent increase of $R_{\mathrm{S}}[10,25]$. The cathodic processes taking place at $-1.2 \mathrm{~V}$ vs. $\mathrm{Cu} / \mathrm{CuSO}_{4}$ are studied and discussed in Section 3.2.

The Nyquist EIS plots obtained for both coupons before the application of CP are compared in Figure 3. Both Nyquist diagrams display similar features, though they are more clearly seen for coupon $\mathrm{WE}_{\mathrm{CP} 2}$. A first capacitive loop is present at high frequency, followed by a linear part and a second capacitive loop at low frequency. The linear part makes angles of $45^{\circ}$ and $50^{\circ}$ with $\operatorname{Re}(Z)$ for coupons $W E_{\mathrm{CP} 1}$ and $W E_{\mathrm{CP} 2}$, respectively. This shows the influence of a diffusional process. Previous studies reported that the cathodic reaction of the steel buried in unsaturated soil was indeed partially controlled by the diffusion of $\mathrm{O}_{2}[10,24]$. Actually, the obtained Nyquist diagrams are characteristic of a bounded diffusion phenomenon, i.e., a finite-length diffusion for a planar electrode. At the beginning of the corrosion process, the corrosion product layer is very thin and should not hinder the diffusion of $\mathrm{O}_{2}$. The $\mathrm{O}_{2}$ concentration gradient is then located in the soil itself, as observed in previous work [37].

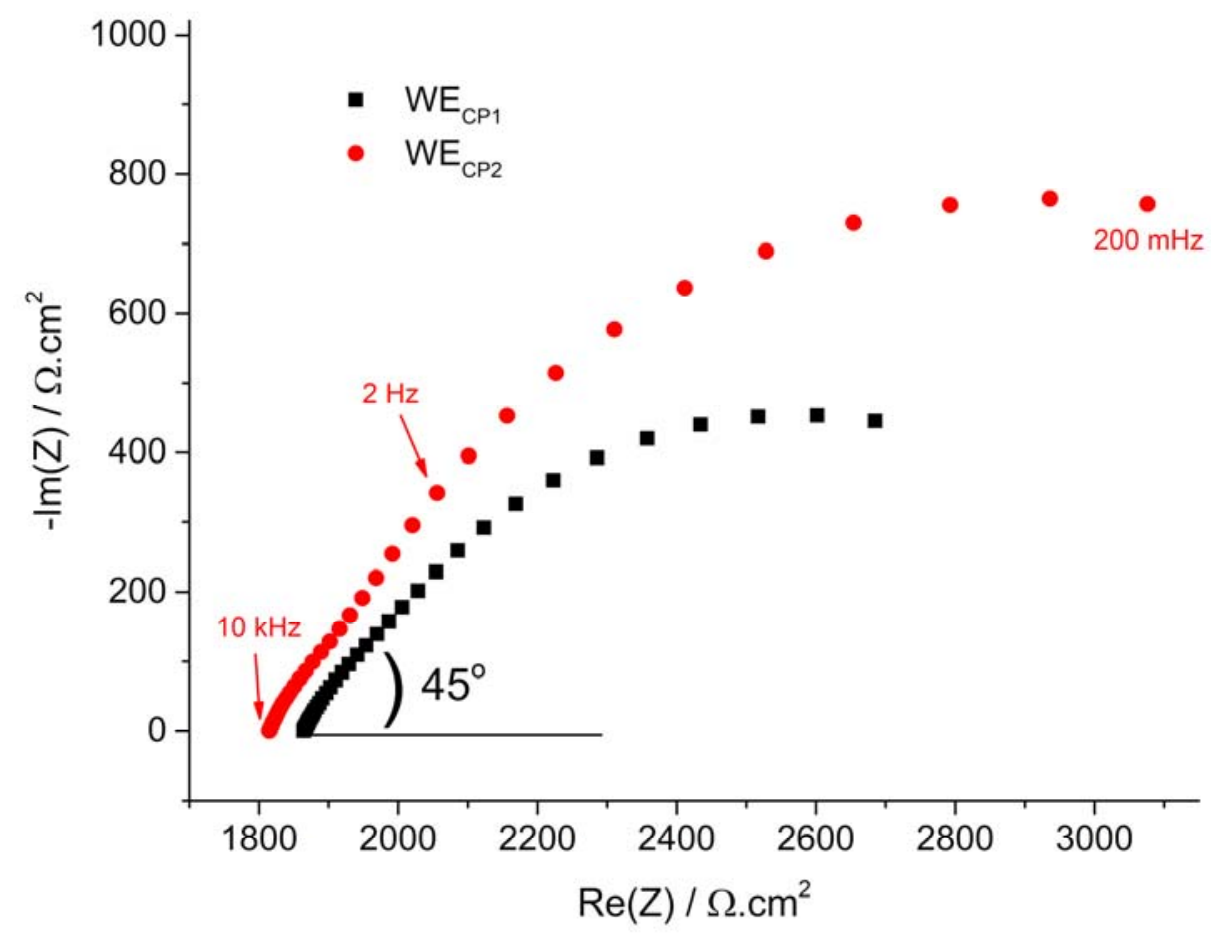

Figure 3. EIS Nyquist at $\mathrm{OCP}$ (day 7) for coupons $\mathrm{WE}_{\mathrm{CP} 1}$ and $\mathrm{WE}_{\mathrm{CP} 2}$.

The EIS data at OCP were then modelled using the electrical equivalent circuit (EEC) displayed in Figure $4 \mathrm{a}$. In this EEC, $R_{\mathrm{s}}$ is the soil electrolyte resistance, $R_{\mathrm{t}}$ is the charge transfer resistance, $Q_{\mathrm{dl}}$ a constant phase element (CPE) used to represent the double layer capacitance and $W_{\mathrm{d}}$ is a bounded diffusion impedance. The CPE was used instead of an ideal capacitance because the first attempts to model the experimental data, performed with a capacitance, did not lead to acceptable goodness-of-fit. Actually, CPE is commonly used 
because it takes into account various effects due to inhomogeneity, porosity, roughness and other non-ideal dielectric properties of the electrode [38]. The results obtained via this modelling are discussed together with those obtained for the coupons under $\mathrm{CP}$ at the end of this section.

(a)

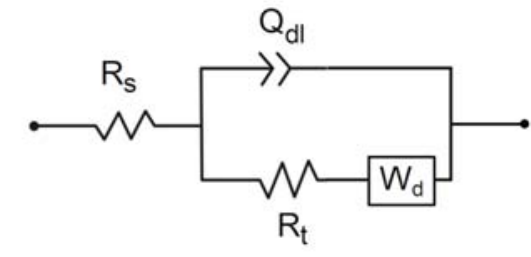

(b)

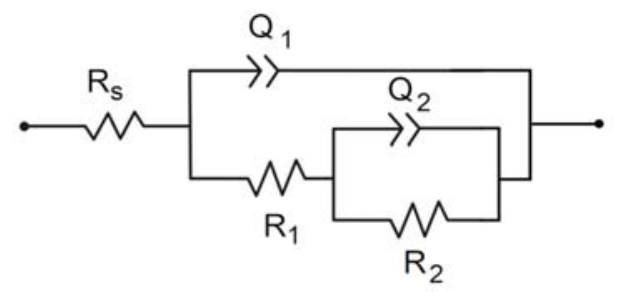

Figure 4. EEC used to fit the EIS data obtained at OCP (a) or under $\mathrm{CP}(\mathbf{b})$ for both coupons.

The influence of CP can be observed on the Nyquist plots of Figures 5 and 6. As explained in Section 2.3.2, only the data obtained after day 42 are discussed. These Nyquist diagrams consistently exhibit a flattened semi-circle loop, followed by what may be an incomplete second loop at lower frequency. The main flattened semi-circle loop is characterized, like that observed at OCP, by a linear behavior at high frequency. However, the initial linear part of the Nyquist diagrams obtained under CP after day 42 makes an angle of $30^{\circ}$ and $25^{\circ}$ with $\operatorname{Re}(Z)$ for coupons $\mathrm{WE}_{\mathrm{CP} 1}$ and $\mathrm{WE}_{\mathrm{CP} 2}$, respectively, as illustrated on day 42 Nyquist plot in Figure 5 and day 63 Nyquist plot in Figure 6. This suggests that the steel coupons behave as semi-infinite porous conductive electrodes $[37,39,40]$. The cathodic process, predominant under $\mathrm{CP}$, would then involve the diffusion of $\mathrm{O}_{2}$ inside the pores of a conductive mineral film covering the steel surface and its reduction all along the conductive walls of the pores. At OCP, the initial linear part of the Nyquist diagram made an angle of about $45^{\circ}$ with the $\operatorname{Re}(\mathrm{Z})$ axis (Figure 3$)$. The impedance, mainly corresponding to a bounded diffusion impedance, then described the diffusion rate of oxygen through a non-conducting porous layer, which in the present case was more likely the soil itself. At day 42 , i.e., after 35 days under $\mathrm{CP}$, the impedance describes the diffusion (and reduction) of $\mathrm{O}_{2}$ in the pores of a conductive layer that formed later under $\mathrm{CP}$.

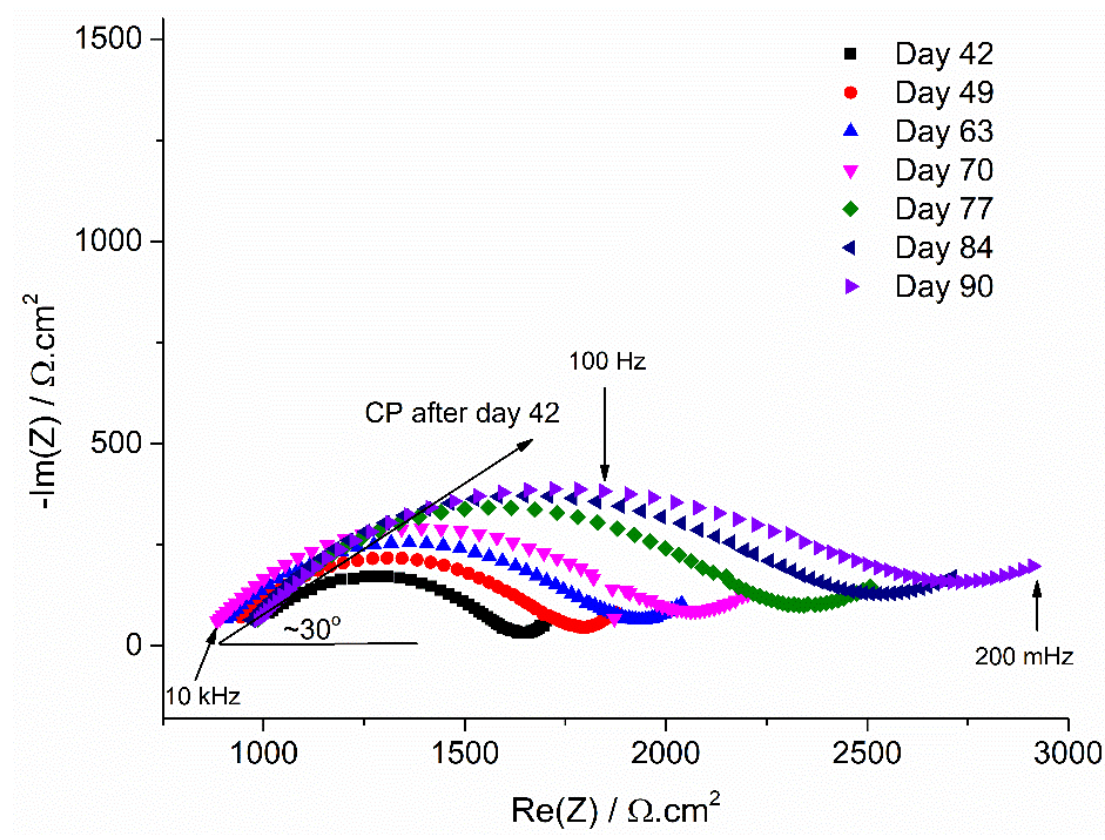

Figure 5. Evolution of the EIS Nyquist plots with exposure time for coupon $\mathrm{WE}_{\mathrm{CP} 1}\left(E_{\mathrm{CP}}=-1.0 \mathrm{~V}\right.$ vs. $\mathrm{Cu} / \mathrm{CuSO}_{4}$ ) between days 42 and 90 . 


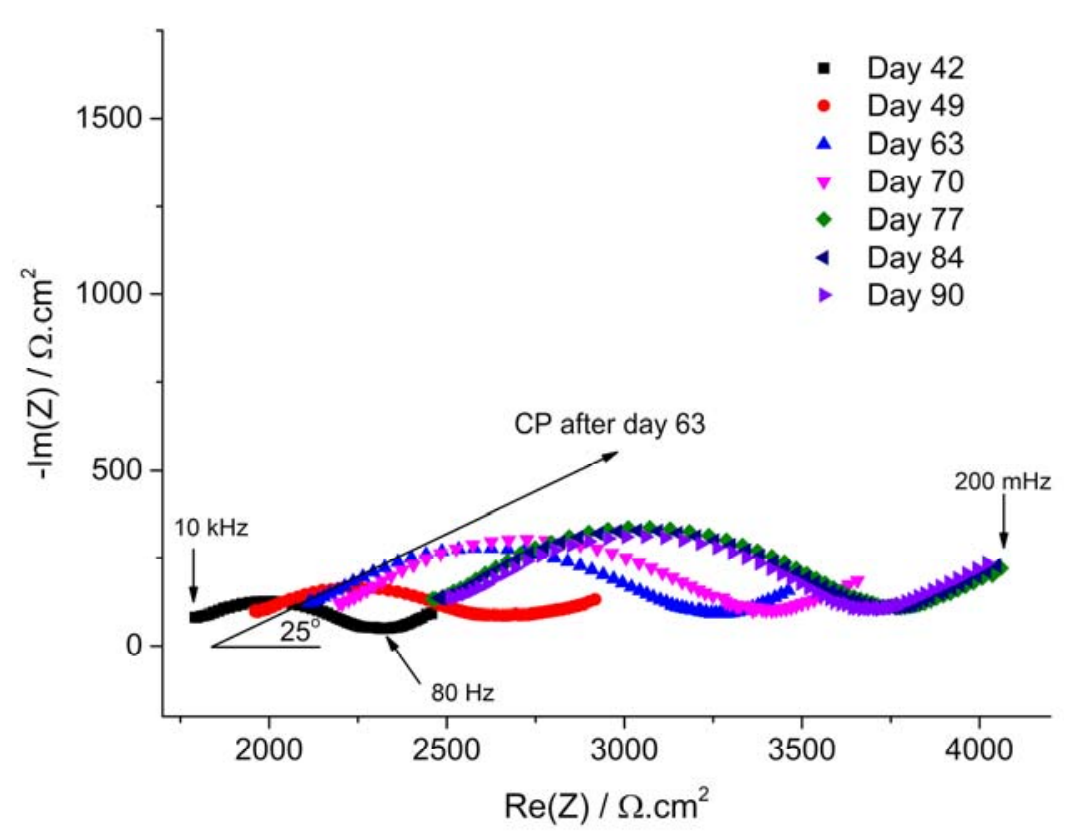

Figure 6. Evolution of the EIS Nyquist plots with exposure time for coupon $\mathrm{WE}_{\mathrm{CP} 2}\left(E_{\mathrm{CP}}=-1.2 \mathrm{~V}\right.$ vs. $\mathrm{Cu} / \mathrm{CuSO}_{4}$ ) between days 42 and 90.

Furthermore, the influence of the applied potential is also clearly revealed. In the case of the $\mathrm{CP}$ potential of $-1.0 \mathrm{~V}$ vs. $\mathrm{Cu} / \mathrm{CuSO}_{4}$, i.e., coupon $\mathrm{WE}_{\mathrm{CP} 1}$ as shown in Figure 5, the flattened semi-capacitive loop at high frequency of the Nyquist plots is observed to increase in magnitude with exposure time. In the present case, the electrochemical process is mainly controlled by the diffusion of $\mathrm{O}_{2}$ inside the pores of the mineral film covering the steel surface. Consequently, the gradual increase of the resistance associated with this electrochemical process indicates that the mineral film hinders more and more efficiently the diffusion of $\mathrm{O}_{2}$.

In the case of excessive $\mathrm{CP}$, i.e., coupon $\mathrm{WE}_{\mathrm{CP} 2}$ as shown in Figure 6, the evolution of the Nyquist plots with exposure time is significantly different. The main difference relates to the evolution of $R_{\mathrm{s}}$, whose value increases with time in this case (see also Figure 2). The diameter of the main flattened loop increases with time between day 42 and day 63, as observed for coupon $\mathrm{WE}_{\mathrm{CP} 1}$, but does not seem to increase afterwards.

To obtain additional information and quantify the evolution of the steel/soil interface with time, a modelling of the EIS data obtained for the coupons under $\mathrm{CP}$ was achieved. The EEC used for both coupons is displayed in Figure $4 \mathrm{~b}$. In this EEC, $Q_{1}$ and $R_{1}$ are a CPE and a resistance, respectively, used to model the phenomenon associated with the main flattened capacitive loop present in all cases (Figures 5 and 6). $Q_{2}$ and $R_{2}$ are the elements used to fit the low frequency part of the impedance diagram. Because only a very small part of the corresponding capacitive loop (if one assumes this is really a capacitive loop) is seen, various values could be obtained for $Q_{2}$ and $R_{2}$ parameters and consequently these parameters are not presented nor discussed. Various fits were performed, with different values for $R_{2}$ and $Q_{2}$, to study the influence of these parameters on the values obtained for $R_{1}$ and $Q_{1}$. It was noted that $R_{1}$ and $Q_{1}$ were not significantly influenced by $R_{2}$ and $Q_{2}$. The considered EEC led to satisfactory fittings of the experimental data, as illustrated by Figure 7.

Figure 7a shows as an example the Nyquist plot for coupon $\mathrm{WE}_{\mathrm{CP} 1}$ at $\mathrm{OCP}$ (day 7) and Table 2 gathers the results obtained for both coupons at OCP. It can be seen that the numerical values are similar for both coupons, except for resistance $R_{\mathrm{d}}$. In the expression of the bounded diffusion impedance $W_{\mathrm{d}}, R_{\mathrm{d}}$ is a scaling factor that depends on the kinetics of the interfacial reaction and the bulk concentration of the electroactive species. The larger value of $R_{\mathrm{d}}$ for coupon $\mathrm{WE}_{\mathrm{CP} 2}$ suggests a lower $\mathrm{O}_{2}$ concentration. This would indicate a faster $\mathrm{O}_{2}$ consumption at the vicinity of coupon $\mathrm{WE}_{\mathrm{CP} 2}$. This faster evolution may also 
correlate with the faster evolution of $R_{\mathrm{S}}$ observed for this coupon between day 1 and day 7 (Figure 2). In conclusion, both coupons behave quite similarly at $\mathrm{OCP}$, as confirmed by voltammetry measurements (Section 3.2).
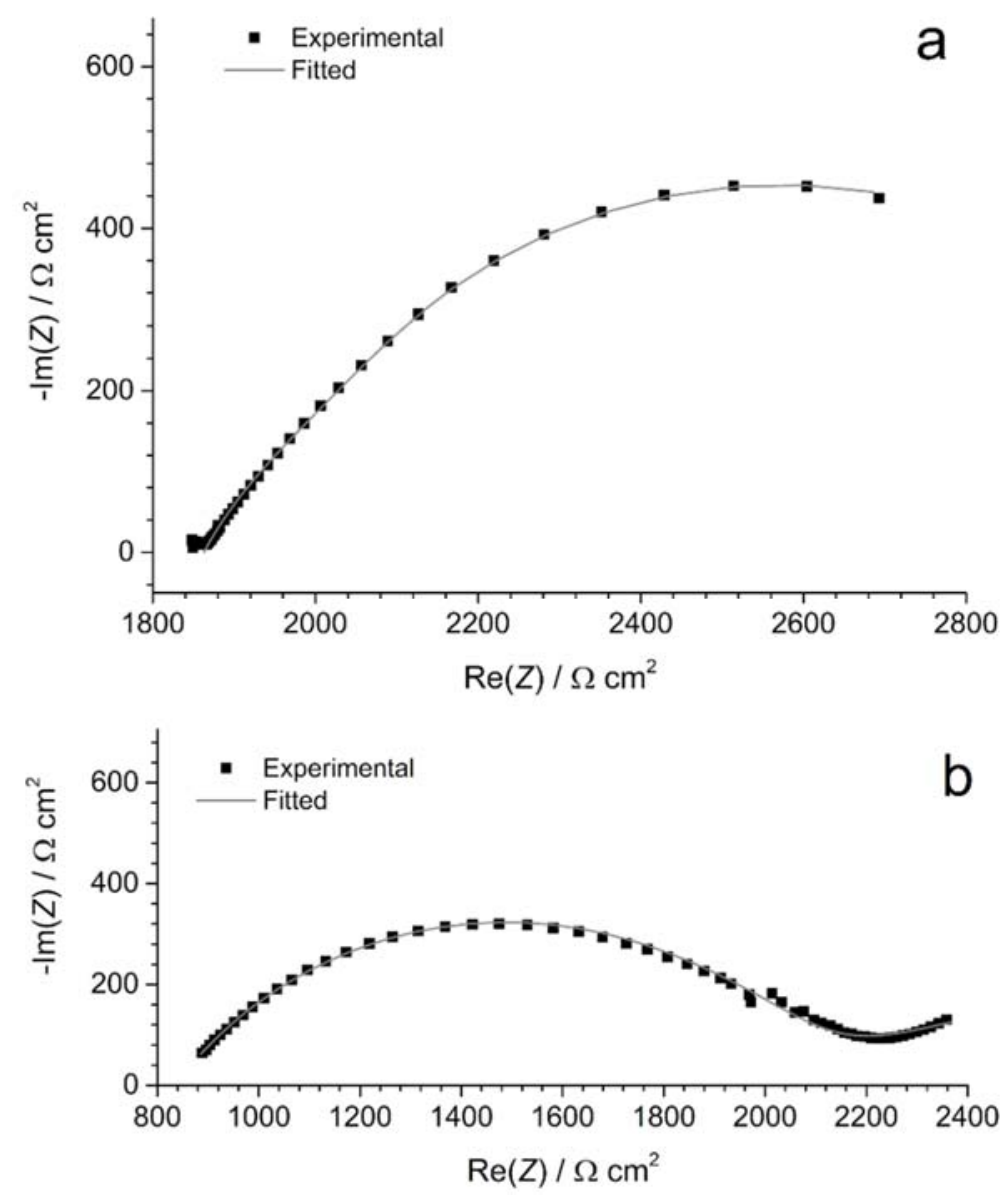

Figure 7. EIS modelling: Nyquist plots for coupon $\mathrm{WE}_{\mathrm{CP} 1}(\mathbf{a})$ at $\mathrm{OCP}$ at day 7 and (b) under $\mathrm{CP}$ at day 70 . Owing to a lower $R_{\mathrm{s}}$ value, the data obtained at day 70 were usable from $100 \mathrm{kHz}$ to $100 \mathrm{mHz}$.

Table 2. Fitted values of EIS data for both coupons at OCP (day 7).

\begin{tabular}{|c|c|c|c|c|c|c|}
\hline Coupon & $R_{\mathrm{s}}\left(\Omega \mathrm{cm}^{2}\right)$ & $n$ & $R_{\mathrm{t}}\left(\Omega \mathrm{cm}^{2}\right)$ & $R_{\mathrm{d}}\left(\Omega \mathrm{cm}^{2}\right)$ & $t_{\mathrm{d}}(\mathrm{s})$ & $\begin{array}{c}Q_{\mathrm{dl}} \\
\left(\mathrm{F} \mathrm{cm}^{-2} \mathrm{~s}^{\mathrm{n}-1}\right)\end{array}$ \\
\hline $\mathrm{WE}_{\mathrm{CP} 1}$ & 1864 & 0.70 & 566 & 841 & 0.39 & $4.2 \times 10^{-4}$ \\
\hline$W E_{C P 2}$ & 1816 & 0.72 & 455 & 1818 & 0.35 & $2.8 \times 10^{-4}$ \\
\hline
\end{tabular}

Figure $7 \mathrm{~b}$ shows as an example the Nyquist plot for coupon $\mathrm{WE}_{\mathrm{CP} 1}$ under $\mathrm{CP}$ at day 70, and Table 3 gathers the results obtained between days 42 and 90 for both coupons. First, as observed qualitatively using the Nyquist plots of Figures 5 and 6, the resistance $R_{1}$ associated with the main capacitive loop increases continuously with time for coupon $W E_{C P 1}$, to reach a maximum of $1661 \Omega \mathrm{cm}^{2}$ at day 90 . For coupon $W E_{C P 2}$, after an initial increase between days 42 and 63 , where a maximum of $1334 \Omega \mathrm{cm}^{2}$ is reached, $R_{1}$ decreases slightly to end at $1230 \Omega \mathrm{cm}^{2}$. 
Table 3. Fitted values of EIS data for coupons $\mathrm{WE}_{\mathrm{CP} 1}$ and $\mathrm{WE}_{\mathrm{CP} 2}$ under $\mathrm{CP}$.

\begin{tabular}{cccccc}
\hline Coupon & Time (d) & $\boldsymbol{R}_{\mathbf{s}}\left(\boldsymbol{\Omega} \mathbf{~ c m}^{\mathbf{2}}\right)$ & $\boldsymbol{R}_{\mathbf{1}}\left(\boldsymbol{\Omega} \mathbf{~ c m}^{\mathbf{2}}\right)$ & $n$ & $\begin{array}{c}Q_{\mathbf{1}} \\
\left(\mathbf{F ~ c m} \mathbf{~ s}^{\mathbf{n}-\mathbf{1}}\right)\end{array}$ \\
\hline $\mathrm{WE}_{\mathrm{CP} 1}$ & 42 & 940 & 659 & 0.60 & $2.8 \times 10^{-6}$ \\
& 49 & 898 & 834 & 0.59 & $4.2 \times 10^{-6}$ \\
& 63 & 838 & 1179 & 0.59 & $4.5 \times 10^{-6}$ \\
& 70 & 834 & 1255 & 0.59 & $4.4 \times 10^{-6}$ \\
& 77 & 930 & 1362 & 0.59 & $4.2 \times 10^{-6}$ \\
& 84 & 916 & 1534 & 0.58 & $5.3 \times 10^{-6}$ \\
$\mathrm{WE}_{\mathrm{CP} 2}$ & 926 & 1661 & 0.56 & $6.3 \times 10^{-6}$ \\
& 42 & 1711 & 595 & 0.53 & $7.5 \times 10^{-6}$ \\
& 49 & 1852 & 707 & 0.52 & $6.4 \times 10^{-6}$ \\
& 63 & 2142 & 1334 & 0.58 & $3.1 \times 10^{-6}$ \\
& 70 & 2241 & 1318 & 0.57 & $3.6 \times 10^{-6}$ \\
& 77 & 2382 & 1253 & 0.58 & $3.5 \times 10^{-6}$ \\
& 84 & 2382 & 1254 & 0.59 & $2.8 \times 10^{-6}$ \\
& 90 & 2425 & 1230 & 0.58 & $3.2 \times 10^{-6}$ \\
\hline
\end{tabular}

It is interesting to note that the $n$ coefficient of the CPE is low, between 0.52 and 0.60 considering both coupons. This coefficient measures the deviation from an ideal behavior, i.e., $n=1$ for a true capacitor and $n<1$ for a CPE. However, a "real" CPE is characterized by $n$ values higher than 0.7 , and $n=0.5$ corresponds to a diffusion element. The values of $n$ obtained here in each case confirm that the cathodic process, i.e., mainly oxygen reduction, is strongly influenced by diffusion. Parameter $R_{1}$ can then be considered as a "resistance to diffusion" induced by the mineral layer growing on the steel surface and inside the pores of the soil. For coupon $\mathrm{WE}_{\mathrm{CP} 1}$, the continuous increase of this resistance shows that this layer is more and more protective as it grows with time. Simultaneously, the CPE element $Q_{1}$ also increases continuously with time. It was observed that the Nyquist plots corresponded to a porous conductive electrode behavior, more likely due to the formation of a porous magnetite layer $[20,27]$. The growth of this conductive layer would increase the overall cathodic surface, thus leading to an increase of the associated capacitance.

Moreover, the increase of $R_{1}$ for coupon $W E_{C P 1}$ is not associated with an increase of $R_{\mathrm{S}}$, which indicates that this increased "resistance to diffusion" is not in any case associated with a decrease in the active area of the electrode. It can really be attributed to the growth of the porous conductive layer that covers the steel surface and progressively hinders more and more the transport of $\mathrm{O}_{2}$.

In the case of coupon $\mathrm{WE}_{\mathrm{CP} 2}$, the initial increase of $R_{1}$ is associated with an increase of $R_{\mathrm{S}}$ that may be due to a decrease of the active area [25]. However, $R_{\mathrm{S}}$ increases from $1711 \Omega \mathrm{cm}^{2}$ to $2142 \Omega \mathrm{cm}^{2}$ between day 42 and day 63 , i.e., an increase of $+25 \%$, while $R_{1}$ increases from $595 \Omega \mathrm{cm}^{2}$ to $1334 \Omega \mathrm{cm}^{2}$, i.e., an increase of $+124 \%$. Consequently, the main reason for this initial increase of $R_{1}$ is not the possible decrease of the active area but, as for coupon $\mathrm{WE}_{\mathrm{CP} 1}$, a real increase of the "resistance to diffusion" associated with the growth of the porous conductive layer. However, $R_{1}$ decreases slightly after day 63 , while $Q_{1}$ decreases as soon as day 42 and fluctuates after day 63 . This shows that the protective ability of the porous conductive layer is influenced by a phenomenon that does not take place for coupon $\mathrm{WE}_{\mathrm{CP} 1}$. This could be due to the hydrogen evolution reaction that should be more important at the lower potential of $-1.2 \mathrm{~V}$ vs. $\mathrm{Cu} / \mathrm{CuSO}_{4}$. Hydrogen evolution could damage, through the release of $\mathrm{H}_{2}$ bubbles, the porous conductive layer. This point is discussed further at the end of Section 3.3.

\subsection{Voltammetry and Estimation of Residual Corrosion Rate}

The voltammograms obtained in this study were computer fitted using theoretical kinetic laws. From the EIS experiments, discussed in the previous section, it was observed 
that the cathodic process, mainly linked to $\mathrm{O}_{2}$ reduction, was at least partially controlled by diffusion. Therefore, the mathematical modelling of the voltammograms $j(E)$ used in the present study, adapted from that reported previously $[10,11,25,27]$, was described by the following expression:

$$
j=j_{A}+j_{C}=j_{c o r r} \cdot e^{\beta_{A}\left(E-E_{\text {corr }}\right)}+\frac{1}{\frac{1}{j_{\text {lim }}}-e^{-\beta_{C}\left(E-E_{\text {corr }}\right)} \cdot\left(\frac{1}{j_{\text {corr }}}+\frac{1}{j_{\text {lim }}}\right)}
$$

where $j=$ overall current density, $j_{\mathrm{A}}=$ anodic current density, $j_{\mathrm{C}}=$ cathodic current density, $j_{\text {corr }}=$ corrosion current density, $j_{\text {lim }}=$ limiting current density $\left(\mathrm{O}_{2}\right.$ diffusion $)$ in $\mathrm{A} / \mathrm{cm}^{2}, E_{\text {corr }}=$ corrosion potential in $\mathrm{V}$ vs. $\mathrm{Cu} / \mathrm{CuSO}_{4}, \beta_{\mathrm{A}}=$ anodic Tafel coefficient and $\beta_{\mathrm{C}}=$ cathodic Tafel coefficient for $\mathrm{O}_{2}$ reduction in $\mathrm{V}^{-1}$.

This model corresponds to an anodic process controlled by charge transfer and a cathodic process partially controlled by diffusion (mixed control) $[10,24,25,29]$. The cathodic process is then in this case restricted to $\mathrm{O}_{2}$ reduction. An additional contribution due to water reduction was envisioned. However, this model implied a very large number of adjustable parameters and the procedure proved unreliable as various solutions could be obtained for the fitting of the experimental curves. It was consequently discarded.

Equation (4) was then used in any case to perform the mathematical modelling, and Figure 8 shows as an example the computer fitted $\log |j|$ vs. E voltammogram obtained after 49 days for coupon $\mathrm{WE}_{\mathrm{CP} 1}$. In any case, the quality of the fitting proved excellent, which demonstrates that the electrochemical model was adequate. Actually, at $E_{\mathrm{CP}}=-1.0 \mathrm{~V}$ vs. $\mathrm{Cu} / \mathrm{CuSO}_{4}$, it was indeed expected that the contribution of water reduction was negligible. The current density $j_{\mathrm{A}}\left(E_{\mathrm{CP}}\right)$ was extrapolated from the anodic Tafel $\operatorname{line} \log \left|j_{\mathrm{A}}\right|$ vs. $E$, as illustrated in Figure 8. From the extrapolated $j_{\mathrm{A}}\left(E_{\mathrm{CP}}\right)$ value, the residual corrosion rate $\tau_{\text {rc }}$ was estimated via Faraday's law.

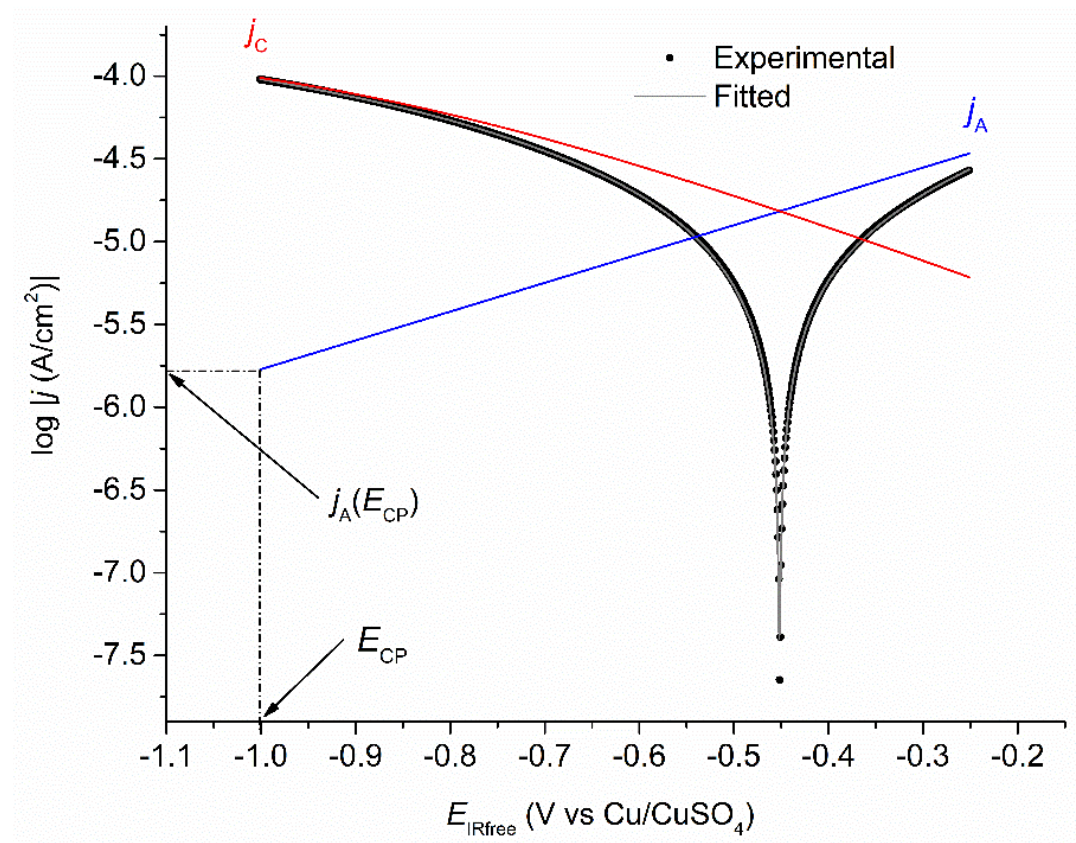

Figure 8. Polarization curves for coupon $\mathrm{WE}_{\mathrm{CP} 1}$ at day 49: experimental-curve (black dots), fittedcurve (grey full line), anodic (blue line) and cathodic (red line) components drawn using the obtained electrochemical parameters. 
All the fitted parameters for coupon $\mathrm{WE}_{\mathrm{CP} 1}$ are listed in Table 4. To facilitate comparison with published data, the Tafel coefficients $\beta_{A, C}$ were converted to Tafel slopes $b_{A, C}$ using the expression:

$$
b_{A, C}=\frac{\ln (10)}{\left|\beta_{A, C}\right|}
$$

Table 4. Summary of fitted parameters computed from mathematical modelling for coupon $\mathrm{WE}_{\mathrm{CP} 1}(\mathrm{CSE}=$ copper/copper sulfate electrode).

\begin{tabular}{|c|c|c|c|c|c|c|c|c|}
\hline Day & $\begin{array}{l}E_{\text {corr }} / \\
\mathrm{V}_{\text {CSE }}\end{array}$ & $\begin{array}{c}j_{\text {corr }} / \\
\mathrm{A} \mathrm{cm}^{-2}\end{array}$ & $\begin{array}{l}j_{\mathrm{A}}\left(E_{\mathrm{CP}}\right) / \\
\mathrm{A} \mathrm{cc^{-2 }}\end{array}$ & $\begin{array}{c}j_{\lim } / \\
A^{c^{\prime} m^{-2}}\end{array}$ & $\begin{array}{c}b_{\mathrm{A} /} \\
\mathrm{mV} / \mathrm{dec}\end{array}$ & $\begin{array}{c}b_{\mathrm{C}}{ }^{\prime} \\
\mathrm{mV} / \mathrm{dec}\end{array}$ & $\begin{array}{c}\tau_{\text {corr }} / \\
\mu \mathrm{mr}^{-1}\end{array}$ & $\begin{array}{c}\tau_{\mathrm{rc}} / \\
\mu \mathrm{m} \mathrm{yr}^{-1}\end{array}$ \\
\hline $\begin{array}{c}7 \\
(\mathrm{OCP})\end{array}$ & -0.85 & $2.86 \times 10^{-5}$ & - & $-1.37 \times 10^{-4}$ & 52 & 62 & 330 & - \\
\hline 42 & -0.54 & $2.71 \times 10^{-5}$ & $1.62 \times 10^{-6}$ & $-3.06 \times 10^{-4}$ & 380 & 290 & - & 19 \\
\hline 49 & -0.45 & $1.52 \times 10^{-5}$ & $1.64 \times 10^{-6}$ & $-5.74 \times 10^{-4}$ & 575 & 460 & - & 19 \\
\hline 63 & -0.37 & $3.01 \times 10^{-5}$ & $1.59 \times 10^{-6}$ & $-5.39 \times 10^{-4}$ & 460 & 575 & - & 18 \\
\hline 70 & -0.45 & $2.45 \times 10^{-5}$ & $1.92 \times 10^{-6}$ & $-1.73 \times 10^{-4}$ & 500 & 440 & - & 22 \\
\hline 77 & -0.41 & $2.10 \times 10^{-5}$ & $6.23 \times 10^{-7}$ & $-1.88 \times 10^{-4}$ & 380 & 380 & - & 7 \\
\hline 84 & -0.38 & $2.45 \times 10^{-5}$ & $6.07 \times 10^{-7}$ & $-1.97 \times 10^{-4}$ & 380 & 460 & - & 7 \\
\hline 90 & -0.36 & $2.78 \times 10^{-5}$ & $6.20 \times 10^{-7}$ & $-2.00 \times 10^{-4}$ & 420 & 480 & - & 7 \\
\hline
\end{tabular}

The accuracy of the obtained values is about $\pm 10 \%$ in any case. For $E_{\text {corr }}$, determined for coupon $\mathrm{WE}_{\mathrm{CP} 1}$ directly on the graph and not through the fitting procedure, the accuracy is $\pm 1 \mathrm{mV}$.

Firstly, the voltammetry measurements performed on day 7 just before the application of $\mathrm{CP}$ revealed that the corrosion rate $\tau_{\text {corr }}$ was $330 \mu \mathrm{m} \mathrm{yr}^{-1}$. This value is consistent with that obtained for a similar saturation level ( $70-60 \%$ sat.) in a previous work performed in the same artificial soil [10]. After 42 days of experiment (35 days of $\mathrm{CP}$ ), the residual corrosion rate $\tau_{\mathrm{rc}}$ of coupon $\mathrm{WE}_{\mathrm{CP} 1}$ was estimated at $19 \mu \mathrm{m} \mathrm{yr}^{-1}$. It decreased to $7 \mu \mathrm{m} \mathrm{yr}^{-1}$ after 77 days in soil (70 days of $\mathrm{CP}$ ) and remained constant until the end of the experiment.

Table 4 also shows that under $\mathrm{CP}, E_{\text {corr }}$ increased from -0.54 vs. $\mathrm{Cu} / \mathrm{CuSO}_{4}$ after 42 days in soil ( 35 days of $\mathrm{CP}$ ) to a final value of $-0.36 \mathrm{~V}$ vs. $\mathrm{Cu} / \mathrm{CuSO}_{4}$ after 90 days in soil ( 83 days of $\mathrm{CP}$ ). These values are much higher than the initial $E_{\text {corr }}$ value measured at OCP. It illustrates the major changes induced by $\mathrm{CP}$ at the steel/electrolyte interface. The main change is the increase in interfacial $\mathrm{pH}$, which itself can induce other effects, e.g., calcareous deposition or passivation of the steel surface.

The differences observed between the Tafel coefficients measured at OCP and those obtained when the coupon is under $\mathrm{CP}$ also reveal the strong influence of $\mathrm{CP}$ on the steel/soil interface. The application of $\mathrm{CP}$ actually led to a significant increase of $b_{\mathrm{A}}$ from $52 \mathrm{mV} /$ decade at OCP to an average value of $440 \mathrm{mV} /$ decade under CP. Similarly, $b_{\mathrm{C}}$ increased from $62 \mathrm{mV} /$ decade to the same average of $440 \mathrm{mV} /$ decade. This phenomenon was already observed in a previous study [27] conducted in similar soil environment and was attributed to the presence of a magnetite layer. The anodic reaction could involve the $\mathrm{Fe}(\mathrm{II}, \mathrm{III})$ cations inside the magnetite layer and the dissolution of the oxide, thus varying $b_{\mathrm{A}}$. Similarly, $b_{\mathrm{C}}$ could vary because $\mathrm{O}_{2}$ reduction can take place on the magnetite layer and not necessarily on the steel surface. Finally, the limiting current density $\left|j_{\text {lim }}\right|$ seems to have decreased slightly with time as the larger (absolute) values are observed at days 42-63 and the lower (absolute) values at days 70-90.

For coupon $\mathrm{WE}_{\mathrm{CP} 2}$ polarized at a lower potential of $-1.2 \mathrm{~V}$ vs. $\mathrm{Cu} / \mathrm{CuSO}_{4}$, the influence of water reduction could be significant. However, $\mathrm{O}_{2}$ reduction seems to be predominant because the EIS data, similar to those obtained for coupon $\mathrm{WE}_{\mathrm{CP} 1}$, revealed the importance of a diffusional process. As explained above, due to an excessive number of adjustable parameters, it proved unreliable to add another cathodic process to the modelling. Therefore, the voltammograms obtained for coupon $\mathrm{WE}_{\mathrm{CP} 2}$ were also computer- 
fitted using Equation (4). Acceptable fittings were achieved, as illustrated in Figure 9 with the voltammogram obtained after 49 days in soil.

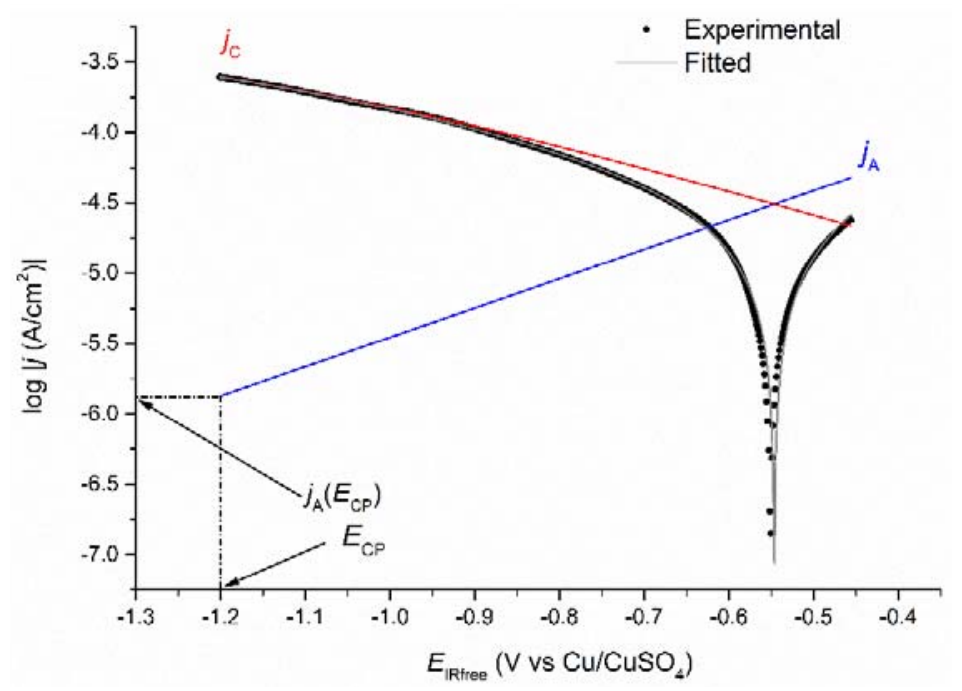

Figure 9. Polarization curves for coupon $\mathrm{WE}_{\mathrm{CP} 2}$ at day 49: experimental-curve (black dots), fittedcurve (grey full line), anodic (blue line) and cathodic (red line) components drawn using the obtained electrochemical parameters.

The quality of the fittings was, however, not as good as that achieved for coupon $W E_{C P 1}$. In Figure 9, it can be seen that a slight shift of $E_{\text {corr }}$ proved necessary to obtain this fitting. Figure 10 shows a focus on the zone where the discrepancy between experimental and fitted curves is the highest. Figure 10a relates to coupon $\mathrm{WE}_{\mathrm{CP} 2}$ and shows some important discrepancies around $E_{\text {corr }}$ and in the $E_{\text {IRfree }}$ region extending from -0.60 to $-0.65 \mathrm{~V}$ vs. $\mathrm{Cu} / \mathrm{CuSO}_{4}$. Figure $10 \mathrm{~b}$ relates to coupon $\mathrm{WE}_{\mathrm{CP} 1}$ and shows that the modelling is in this case excellent. This shows that the electrochemical model considered in both cases is completely valid for coupon $\mathrm{WE}_{\mathrm{CP} 1}$ but is only an approximation for coupon $\mathrm{WE}_{\mathrm{CP} 2}$. This can be attributed to a significant contribution of water reduction for $\mathrm{WE}_{\mathrm{CP} 2}$ polarized at $-1.2 \mathrm{~V}$ vs. $\mathrm{Cu} / \mathrm{CuSO}_{4}$.

The fitted parameters obtained for coupon $\mathrm{WE}_{\mathrm{CP} 2}$ are listed in Table 5. Due to the lower goodness-of-fit, the accuracy is in this case about $\pm 20 \%$, as high as $\pm 50 \%$ for the parameters linked to the cathodic reaction, i.e., $b_{\mathrm{C}}$ and $j_{\text {lim }}$. As already demonstrated in other sections of the study, the application of $\mathrm{CP}$ after the first 7 days of the experiment induced significant changes on the steel/electrolyte interface. The evolution of $E_{\mathrm{corr}}, b_{\mathrm{A}}$ and $b_{\mathrm{C}}$ observed for coupon $\mathrm{WE}_{\mathrm{CP} 1}$ are also observed for coupon $\mathrm{WE}_{\mathrm{CP} 2}$. $E_{\mathrm{corr}}$ is increased by the application of $\mathrm{CP}$ and reaches $-0.369 \mathrm{~V}$ vs. $\mathrm{Cu} / \mathrm{CuSO}_{4}$ at day 90 . Tafel slopes $b_{\mathrm{A}}$ and $b_{\mathrm{C}}$ are also increased by $\mathrm{CP}$, to average values of $510 \mathrm{mV} /$ decade and $660 \mathrm{mV} /$ decade, respectively. The standard deviation on the $b_{\mathrm{A}}$ values is $60 \mathrm{mV} /$ decade $( \pm 12 \%)$, which shows that the accuracy of the anodic Tafel slope is correct, i.e., not too strongly influenced by the imperfect modelling of the cathodic reaction. This is a crucial point because the estimation of the residual corrosion rate is primary linked to the anodic Tafel slope $b_{\mathrm{A}}$. By comparison, the standard deviation for the $b_{C}$ values is $285 \mathrm{mV} /$ decade $( \pm 43 \%)$. The error on $j_{\text {lim }}$ is also important, and the values vary around an average of $-5 \times 10^{-4}$, with no apparent link with the polarization time. This can also be attributed to the influence of water reduction.

Similarly, the variations of the residual corrosion rate over time are different for $\mathrm{WE}_{\mathrm{CP} 1}$ and $\mathrm{WE}_{\mathrm{CP} 2}$. Figure 11 thus presents the evolution of $\tau_{\mathrm{rc}}$ with exposure time in soil for both coupons. Firstly, it can be clearly observed that the application of $\mathrm{CP}$ led to a significant decrease in steel corrosion rate. Between days 42 and 70, the residual corrosion rate reaches values between 18 and $22 \mu \mathrm{m} \mathrm{yr}^{-1}$ for coupon $\mathrm{WE}_{\mathrm{CP} 1}$ and between 8 and $15 \mu \mathrm{m} \mathrm{yr}^{-1}$ for coupon $\mathrm{WE}_{\mathrm{CP} 2}$, while the corrosion rates were estimated at $330 \mu \mathrm{m} \mathrm{yr}^{-1}$ and $370 \mu \mathrm{m} \mathrm{yr}^{-1}$, 
respectively, at OCP on day 7 . This result is consistent with what could be expected: the lower the potential, the lower the anodic component of the overall current density (as illustrated by the anodic Tafel lines of Figures 8 and 9).
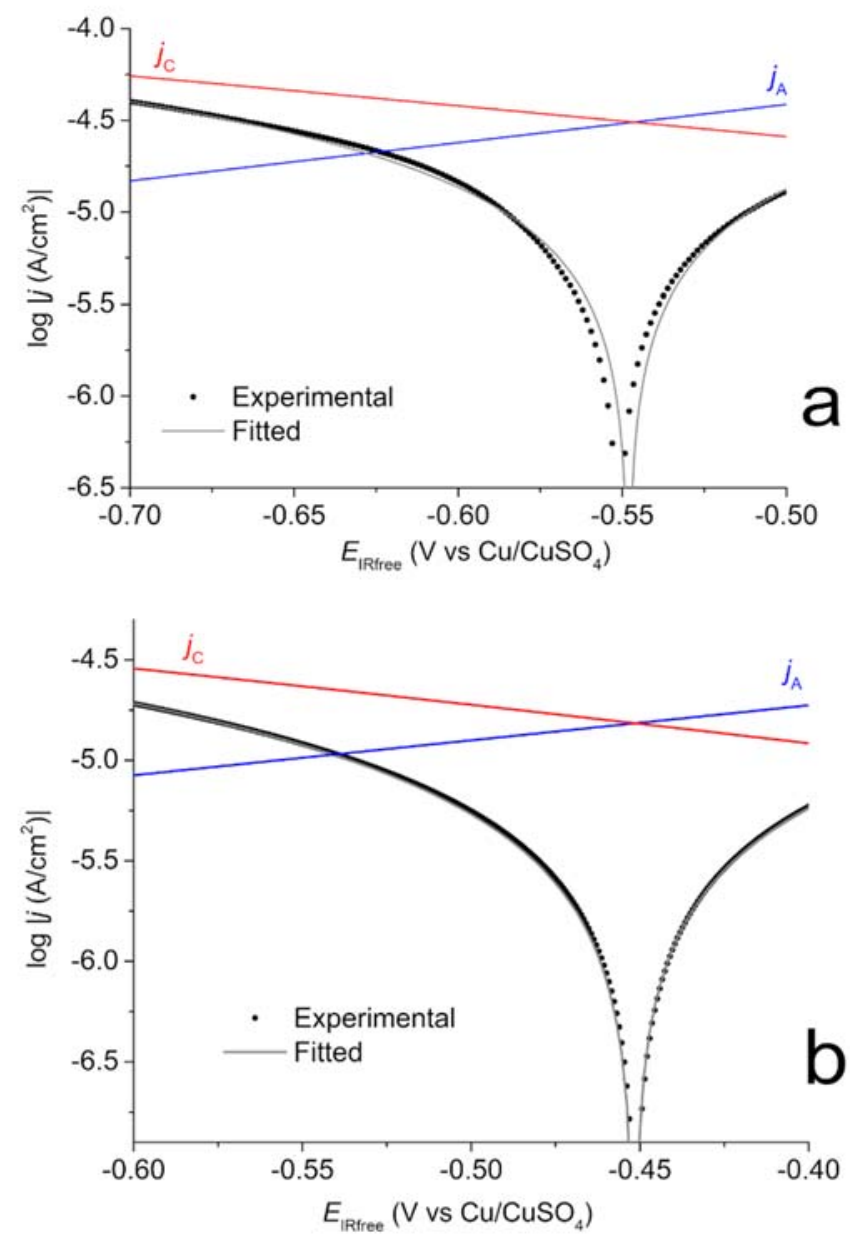

Figure 10. Polarization curves for coupons $\mathrm{WE}_{\mathrm{CP} 2}(\mathbf{a})$ and $\mathrm{WE}_{\mathrm{CP} 1}$ (b) at day 49: detailed view. Experimental-curve (back dots), fitted-curve (grey full line), anodic (blue line) and cathodic (red line) components drawn using the obtained electrochemical parameters.

Table 5. Summary of the fitted parameters computed from mathematical modelling for coupon $\mathrm{WE}_{\mathrm{CP} 2}(\mathrm{CSE}=$ copper/copper sulfate electrode). The values for $b_{\mathrm{C}}$ and $j_{\lim }$ are in brackets as the error is high (about $\pm 50 \%$ ).

\begin{tabular}{|c|c|c|c|c|c|c|c|c|}
\hline Day & $\begin{array}{l}E_{\text {corr }} / \\
\mathrm{V}_{\text {CSE }}\end{array}$ & $\begin{array}{c}j_{\text {corr }} / \\
\mathrm{A} \mathrm{cm}^{-2}\end{array}$ & $\begin{array}{l}j_{\mathrm{A}}\left(E_{\mathrm{CP}}\right) / \\
\mathrm{A} \mathrm{cm} \mathrm{cm}^{-2}\end{array}$ & $\begin{array}{c}j_{\lim } / \\
\mathrm{A} \mathrm{cm}^{-2}\end{array}$ & $\begin{array}{c}b_{\mathrm{A}} / \\
\mathrm{mV} / \mathrm{dec}\end{array}$ & $\begin{array}{c}b_{\mathrm{C}}{ }^{\prime} \\
\mathrm{mV} / \mathrm{dec}\end{array}$ & $\begin{array}{c}\tau_{\text {corr }} / \\
\mu \mathrm{mr}^{-1}\end{array}$ & $\begin{array}{c}\tau_{\mathrm{rc}} / \\
\mu \mathrm{m} \mathrm{yr}^{-1}\end{array}$ \\
\hline $\begin{array}{c}7 \\
(\mathrm{OCP})\end{array}$ & -0.85 & $3.15 \times 10^{-5}$ & - & $-1.19 \times 10^{-4}$ & 82 & 77 & 370 & - \\
\hline 42 & -0.64 & $1.95 \times 10^{-5}$ & $8.96 \times 10^{-7}$ & $\left(-2.3 \times 10^{-4}\right)$ & 415 & (190) & - & 10 \\
\hline 49 & -0.55 & $3.09 \times 10^{-5}$ & $1.32 \times 10^{-6}$ & $\left(-5.0 \times 10^{-4}\right)$ & 480 & $(560)$ & - & 15 \\
\hline 63 & -0.45 & $2.71 \times 10^{-5}$ & $7.24 \times 10^{-7}$ & $\left(-4.7 \times 10^{-4}\right)$ & 470 & (720) & - & 8 \\
\hline 70 & -0.39 & $3.36 \times 10^{-5}$ & $7.94 \times 10^{-7}$ & $\left(-7.3 \times 10^{-4}\right)$ & 500 & (960) & - & 9 \\
\hline 77 & -0.41 & $3.14 \times 10^{-5}$ & $1.29 \times 10^{-6}$ & $\left(-5.9 \times 10^{-4}\right)$ & 575 & $(410)$ & - & 15 \\
\hline 84 & -0.43 & $2.87 \times 10^{-5}$ & $1.10 \times 10^{-6}$ & $\left(-5.6 \times 10^{-4}\right)$ & 550 & (885) & - & 13 \\
\hline 90 & -0.38 & $2.57 \times 10^{-5}$ & $1.00 \times 10^{-6}$ & $\left(-4.3 \times 10^{-4}\right)$ & 575 & (885) & - & 12 \\
\hline
\end{tabular}

After day 70, two opposite trends are observed. For coupon $\mathrm{WE}_{\mathrm{CP} 1}$, polarized at a correct protection potential, $\tau_{\mathrm{rc}}$ decreases to reach a value below $10 \mu \mathrm{m} \mathrm{yr}^{-1}$, i.e., $7 \mu \mathrm{m} \mathrm{yr}^{-1}$ at days 77,84 and 90 . This decrease of the residual corrosion rate to such low values was 
already observed and was attributed to the progressive growth of a protective mineral layer on the steel substrate [23-26]. In contrast, for coupon $\mathrm{WE}_{\mathrm{CP} 2}$ polarized at a lower potential, $\tau_{\text {rc }}$ slightly increases after day 63 , to reach $15 \mu \mathrm{m} \mathrm{yr}^{-1}$ at day 77 before to decrease slightly to $12 \mu \mathrm{m} \mathrm{yr}^{-1}$ at day 90 . In conclusion, the average final (days 77-90) value is $7 \mu \mathrm{m} \mathrm{yr}^{-1}$ for coupon $\mathrm{WE}_{\mathrm{CP} 1}$ and $13 \mu \mathrm{m} \mathrm{yr}^{-1}$ for coupon $\mathrm{WE}_{\mathrm{CP} 2}$. The overprotection did not lead to an increased effectiveness of $\mathrm{CP}$ and seems to have even decreased this effectiveness. It can be assumed that the overprotection, which increases significantly water reduction and then hydrogen evolution, can damage the protecting mineral layer that covers the steel surface. This assumption also explains why, after an initial decrease to $8 \mu \mathrm{m} \mathrm{yr}^{-1}, \tau_{\mathrm{rc}}$ increased later on.

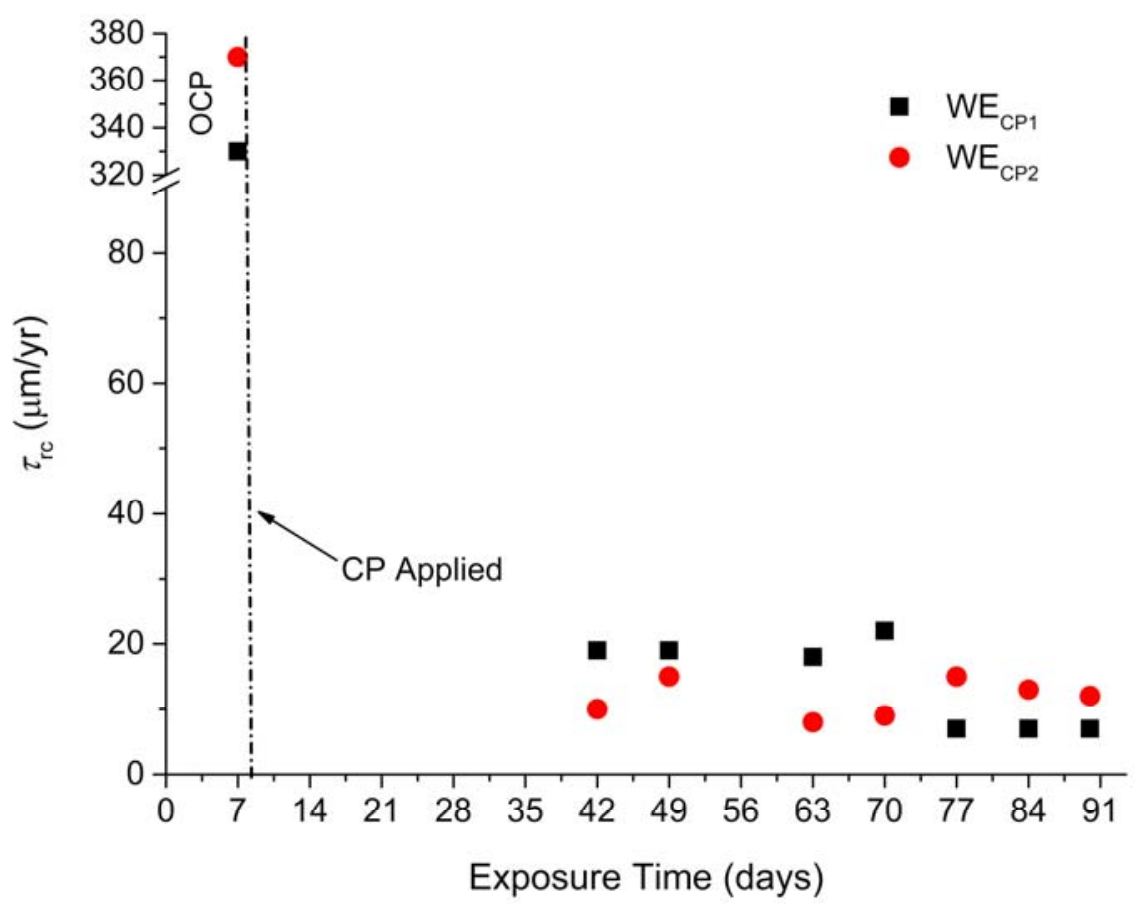

Figure 11. Evolution of the residual corrosion rate over time for coupons $W E_{C P 1}$ and $W E_{C P 2}$.

Two different behaviors were also observed via EIS, in particular for the evolution of $R_{\mathrm{s}}$ over time (Figure 2). For coupon $\mathrm{WE}_{\mathrm{CP} 1}$, the $R_{\mathrm{s}}$ value remained constant after day 42 , which indicates that the steel/soil interface has reached a steady state. Conversely, for coupon $\mathrm{WE}_{\mathrm{CP} 2}, R_{\mathrm{S}}$, after an initial decrease until day 21 , tended to increase regularly with time. This increase of $R_{\mathrm{S}}$ could be associated with a slight decrease of the "wet" or "active" area of the steel electrode $[10,11,25,26]$. This decrease of the active area could be due to the accumulation of $\mathrm{H}_{2}$ bubbles on the surface. The release of such bubbles from time to time would then damage the protective film and lead to the observed increase of $\tau_{\mathrm{rc}}$.

Similarly, the diameter of the main capacitive loop present on the Nyquist diagrams, associated with the "resistance to diffusion" $R_{1}$, was observed to increase continuously with time for coupon $\mathrm{WE}_{\mathrm{CP} 1}$ (Figure 5 and Table 4). This also illustrates the increasing protective ability of the mineral layer forming on the steel surface. The increase of the "resistance to diffusion" was less important in the case of coupon $\mathrm{WE}_{\mathrm{CP} 2}$ (Figure 6 and Table 4) and stopped after day 63 (it even slightly decreased). This result confirms the lesser protectiveness of the layer and is consistent with the increase of $\tau_{\text {rc }}$ observed after day 63 .

It must finally be recalled that the method used here, based on voltammetry, may significantly modify the electrode surface and thus may introduce some side effects and bias. For instance, the steel surface may be passive at $E_{\mathrm{CP}}$, due to the increase of the interfacial $\mathrm{pH}$, and depassivate during the voltammetry experiments. The extrapolation of the anodic Tafel line, which is actually obtained mainly from the potential region around $E_{\text {corr, }}$, would then lead to an overestimation of $\tau_{\mathrm{rc}}$. This depassivation phenomenon may, 
however, take a time longer than that required for the voltammetry experiment. The time required for that depassivation once $\mathrm{CP}$ is interrupted was reported to vary with the size of the electrode, from $1 \mathrm{~h}$ for a $5 \times 5 \mathrm{~mm}$ electrode to $13 \mathrm{~h}$ for a $30 \times 30 \mathrm{~mm}$ electrode [19]. It may, however, depend on the nature of the soil, the composition of the electrolyte present in the soil, the moisture content, the applied potential, etc.

Voltammetry also involves a charging current due to capacitive effects, and the measured current is then the sum of the faradaic current and the charging current [41,42]. When the applied potential is increased linearly with time, at is the case for the polarization curves modelled to estimate the residual corrosion rate, the positive charge density stored at the metal surface increases. In this case, the charging current flows in the direction of the anodic faradaic current [42]. Then, the measured current is necessarily higher than the anodic faradaic current. Because the charging current is proportional to the scan rate [42], the discrepancy between both currents increases with the scan rate, and for that reason a small scan rate of $0.2 \mathrm{mV} / \mathrm{s}$ was considered. In any case, as demonstrated previously [26], these capacitive effects also lead to an overestimation of the residual corrosion rate.

Increasing the potential from $E_{\mathrm{CP}}$ to $\mathrm{OCP}$ decreases the cathodic reaction rate and the $\mathrm{O}_{2}$ consumption rate so that the steel/soil interface may progressively be enriched in dissolved $\mathrm{O}_{2}$. This modification also leads to an additional increase in the corrosion rate, i.e., the anodic component of the current density, which leads to an overestimation of the residual corrosion rate.

In conclusion, it must be noted that the method based on voltammetry more likely overestimates the residual corrosion rate. It may, however, give fruitful information when it is used to compare between two situations, for instance, two different applied potentials as done here. Moreover, the results given by voltammetry can be confronted to those given by EIS, and in the present case both methods led to consistent conclusions. Finally, when residual corrosion rates lower than $10 \mu \mathrm{m} \mathrm{yr}^{-1}$ are obtained using voltammetry, it can be reasonably assumed that the actual residual corrosion rate is indeed lower than this threshold of $10 \mu \mathrm{m} \mathrm{yr}^{-1}$, which is considered to define an "efficient" CP.

\subsection{Characterization of the Mineral Layer Formed on the Steel Coupons}

$\mu$-Raman spectroscopy analysis was performed on the surface of the coupons and on the surface of the soil layer in contact with the steel surface. The same phases were identified in both cases, indicating that the corrosion products not only covered the steel surface but also tended to fill the pores of the soil. The analysis of coupon $\mathrm{WE}_{\mathrm{CP} 1}$ revealed various corrosion products, and two spectra are presented as examples in Figure 12. Spectrum (a) is very similar to that of magnetite $\left(\mathrm{Fe}_{3} \mathrm{O}_{4}\right)$, which is characterized by an intense pic at 663 $676 \mathrm{~cm}^{-1}$, and two smaller peaks at $300-320 \mathrm{~cm}^{-1}$ and $510-550 \mathrm{~cm}^{-1}$ [43-45]. However, in our case, the first peak is found at $365 \mathrm{~cm}^{-1}$ and its intensity, as well as that of the peak at $525 \mathrm{~cm}^{-1}$, is unusually strong. Actually, spectrum (a) also shares typical features with the spectrum of maghemite $\gamma-\mathrm{Fe}_{2} \mathrm{O}_{3}$. Magnetite and maghemite are structurally similar and may be both present. The formation of non-stoichiometric magnetite $\mathrm{Fe}_{3-\mathrm{x}} \mathrm{O}_{4}$, an intermediate between $\mathrm{Fe}_{3} \mathrm{O}_{4}$ and $\gamma-\mathrm{Fe}_{2} \mathrm{O}_{3}$ [46], is also very likely.

Raman spectrum (b) displays the main characteristic peaks of goethite $(\alpha-\mathrm{FeOOH})$ with an intense peak at $388 \mathrm{~cm}^{-1}$ and three smaller peaks at $300 \mathrm{~cm}^{-1}, 547 \mathrm{~cm}^{-1}$ and $692 \mathrm{~cm}^{-1}$. The broad peak at $692 \mathrm{~cm}^{-1}$ is, however, unusually intense, which suggests that magnetite (main peak at $663-676 \mathrm{~cm}^{-1}$ ) is also present in this case.

The analysis of coupon $\mathrm{WE}_{\mathrm{CP} 2}$ gave similar results. The obtained Raman spectra (Figure 13) confirmed that corrosion products did form. Spectrum (a) revealed the presence of lepidocrocite $\gamma-\mathrm{FeOOH}$, clearly identified by its two main peaks at $247 \mathrm{~cm}^{-1}$ and $379 \mathrm{~cm}^{-1}$ [43]. However, broad vibration bands are also visible at $708 \mathrm{~cm}^{-1}, 370 \mathrm{~cm}^{-1}$ and $525 \mathrm{~cm}^{-1}$. They correspond to ferrihydrite, a poorly crystallized and poorly ordered hydrated Fe(III)-oxyhydroxide [47]. The main peak of magnetite is visible at $671 \mathrm{~cm}^{-1}$ as a shoulder of the main band of ferrihydrite. The presence of magnetite could be 
demonstrated more clearly via the analysis of other zones of the steel surface, as illustrated by spectrum (b).

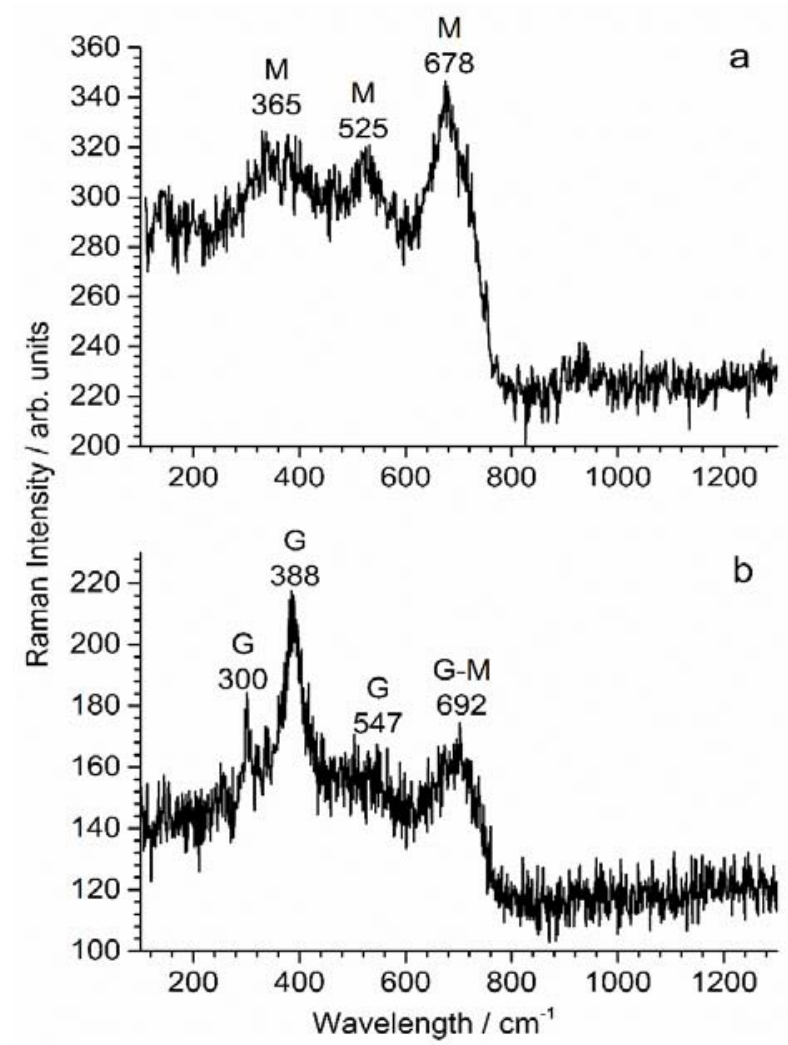

Figure 12. $\mu$-Raman spectroscopy analysis of the surface of coupon $\mathrm{WE}_{\mathrm{CP} 1} ; \mathrm{G}=$ goethite, $\mathrm{M}=$ magnetite/maghemite (see text). See text for the interpretation of spectra $(\mathbf{a}, \mathbf{b})$.

It must be noted that $\mathrm{CaCO}_{3}$ phases could not be detected. First, it is possible that the conditions required for the formation of a calcareous deposit were not met. Secondly, $\mu$-Raman spectroscopy is a local characterization technique, and if $\mathrm{CaCO}_{3}$ formed as a minor component, for instance, in the pores of the magnetite layer, it could have been missed. In any case, the decrease with time of the residual corrosion rate for coupon $W E_{\mathrm{CP} 1}$ can be attributed to the formation of a thin layer of corrosion products.

In conclusion, for both $\mathrm{WE}_{\mathrm{CP} 1}$ and $\mathrm{WE}_{\mathrm{CP} 2}$ coupons, the steel surface proved to be covered by a layer mainly composed of magnetite and various Fe(III) oxyhydroxides. The predominance of magnetite, already observed in previous studies [20,27], can be attributed to the increase of the interfacial $\mathrm{pH}$ [48] induced by the cathodic reactions (see Equations (1) and (2)). Moreover, the cathodic polarization can also induce the reduction of $\mathrm{Fe}(\mathrm{III})$ to $\mathrm{Fe}(\mathrm{II})$ and thus the reduction of $\mathrm{FeOOH}$ compounds into magnetite.

The EIS results, which showed a behavior typical of conductive porous electrode, can then clearly be attributed to the presence of the magnetite-containing layer. Magnetite is an electronic conductor with low resistivity [49], and consequently $\mathrm{O}_{2}$ molecules can be reduced on the walls of the pores of this layer. The term "magnetite layer" may not actually be appropriate. Magnetite was also identified in the pores of the soil at the very vicinity of the steel surface. The "porous electrode" behavior observed via EIS might not be due, strictly speaking, to a porous magnetite layer but rather to a small layer of soil where the pore walls could be covered with interconnected magnetite particles. This would explain how the small amount of magnetite resulting from the residual corrosion process could give rise to this porous electrode behavior. 


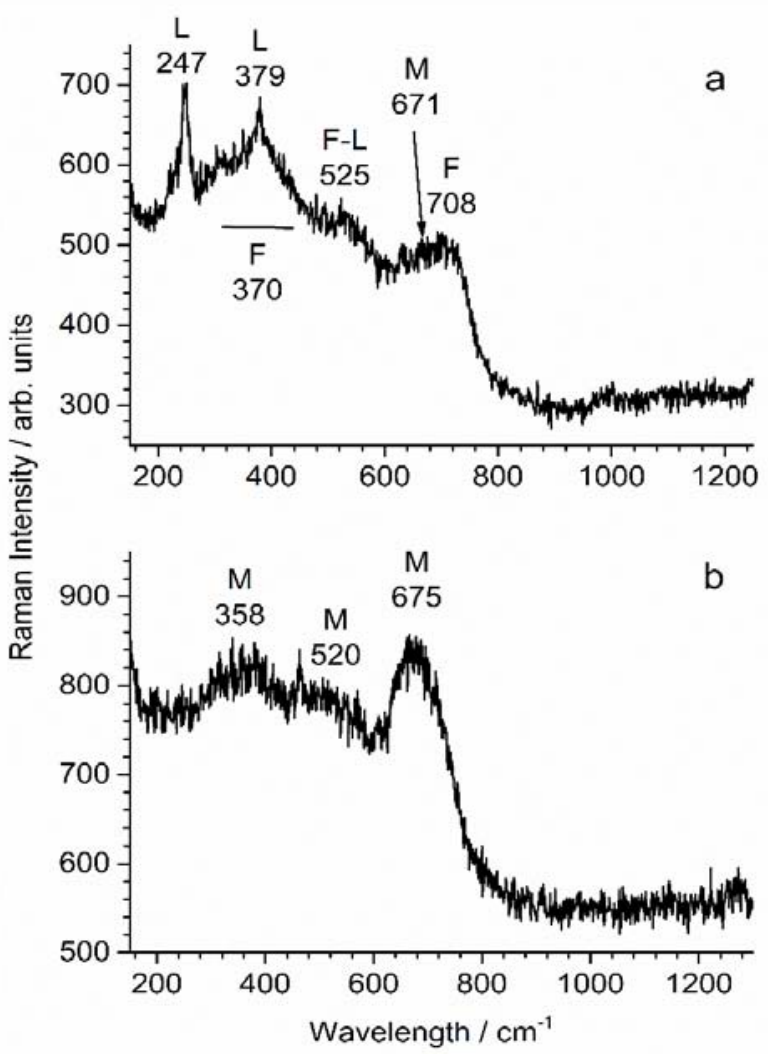

Figure 13. $\mu$-Raman spectroscopy analysis of the surface of coupon $\mathrm{WE}_{\mathrm{CP} 1}$; $\mathrm{G}=$ goethite, $\mathrm{M}=$ magnetite/maghemite. See text for the interpretation of spectra $(\mathbf{a}, \mathbf{b})$.

The higher protective ability of the layer formed at $-1.0 \mathrm{~V}$ vs. $\mathrm{Cu} / \mathrm{CuSO}_{4}$ is not linked to its composition because the corrosion products identified for coupon $\mathrm{WE}_{\mathrm{CP} 2}$ polarized at $-1.2 \mathrm{~V}$ vs. $\mathrm{Cu} / \mathrm{CuSO}_{4}$ proved rather similar. It is therefore due to differences in terms of porosity, compactness and/or adhesion properties. The layer formed at $-1.0 \mathrm{~V}$ vs. $\mathrm{Cu} / \mathrm{CuSO}_{4}$ is more protective because it has fewer defects, which can be attributed to the fact that water reduction is not active. Actually, the release of $\mathrm{H}_{2}$ bubbles at $-1.2 \mathrm{~V}$ vs. $\mathrm{Cu} / \mathrm{CuSO}_{4}$ may have finally damaged this layer, which would explain the increase of the residual corrosion rate observed after day 63 (Figure 11). Water molecules are present in the pores of the corrosion product layer and at the surface of the steel. $\mathrm{H}_{2} \mathrm{O}$ reduction can then take place directly at the metal surface, and $\mathrm{H}_{2}$ molecules can then accumulate on this surface, finally forming $\mathrm{H}_{2}$ bubbles. If trapped between the metal and the protective layer, the bubbles would induce mechanical stresses and eventually cracks in the layer. The $\mathrm{H}_{2}$ bubbles would then be released in the soil through these cracks, and this $\mathrm{H}_{2}$ flow would moreover remove some magnetite particles from the metal surface, move them and finally set them on the pore walls of the soil.

\section{Conclusions}

The application of cathodic protection led, in the experimental conditions considered here, to the formation of a magnetite-rich layer, which resulted from the residual corrosion process occurring under CP [20,23-27]. For both applied potentials, EIS revealed that the steel surface behaved as a porous conductive electrode, which can be attributed to the presence of the magnetite-rich layer.

The voltammetry analysis revealed that steel dissolution was reduced from $330 \mu \mathrm{m} \mathrm{yr}^{-1}$ (after 7 days at OCP) to $7 \mu \mathrm{m} \mathrm{yr}^{-1}$ (after 70 days of $\mathrm{CP}$ ) when the applied cathodic potential $E_{\mathrm{CP}}$ was $-1.0 \mathrm{~V}$ vs. $\mathrm{Cu} / \mathrm{CuSO}_{4}$. Consequently, the $E_{\mathrm{CP}}$ of $-1.0 \mathrm{~V}$ vs. $\mathrm{Cu} / \mathrm{CuSO}_{4}$ led to the full protection of steel as $\tau_{\mathrm{rc}}$ was determined at a constant value smaller than $10 \mu \mathrm{m} \mathrm{yr}^{-1}$ (as recommended by NF EN 12954 standard [14]) toward the end of the experiment. The 
progressive decrease of $\tau_{\mathrm{rc}}$ with time can be attributed to the growth of the layer of (residual) corrosion products. This layer can then be considered as protective at $E_{\mathrm{CP}}=-1.0 \mathrm{~V}$ vs. $\mathrm{Cu} / \mathrm{CuSO}_{4}$. The modelling of EIS results proved consistent with voltammetry analysis and demonstrated that the porous conductive layer forming grew more and more protective with time.

In contrast, voltammetry revealed that the polarization of steel at $E_{C P}=-1.2 \mathrm{~V}$ vs. $\mathrm{Cu} / \mathrm{CuSO}_{4}$ led to an average $\tau_{\mathrm{rc}}$ value of $13 \mu \mathrm{m} \mathrm{yr}^{-1}$ after day 70 , while it reached a smaller value of $8 \mu \mathrm{m} \mathrm{yr}^{-1}$ before. EIS results proved consistent and showed that the protective ability of this layer tended to decrease slightly after day 63 . The variations of the residual corrosion rate are associated with an increase of soil electrolyte resistance $R_{\mathrm{S}}$ that may be due to the accumulation of $\mathrm{H}_{2}$ bubbles on the steel surface. The sporadic release of such bubbles would damage the protective layer and explain the higher residual corrosion rate.

Author Contributions: Conceptualization, P.R., M.J. and M.G.R.M.; methodology, P.R. and M.G.R.M.; software, M.J.; validation, P.R. and M.J.; formal analysis, M.G.R.M. and P.R.; investigation, M.G.R.M. and P.R.; resources, P.A.O.; data curation, M.G.R.M.; writing—original draft preparation, M.G.R.M.; writing-review and editing, P.R.; visualization, P.R.; supervision, P.R. and M.J.; project administration, P.A.O. and P.M.; funding acquisition, P.A.O. and P.R. All authors have read and agreed to the published version of the manuscript.

Funding: This research was funded by NATIONAL RESEARCH FOUNDATION (NRF)-SOUTH AFRICA, grant number 102617.

Institutional Review Board Statement: Not applicable.

Informed Consent Statement: Not applicable.

Data Availability Statement: The data generated during the current study are available from the corresponding author on reasonable request.

Conflicts of Interest: The authors declare no conflict of interest. The funders had no role in the design of the study or in the collection, analyses or interpretation of data.

\section{References}

1. Romanof, M. Underground Corrosion; US Government Printing Office: Washington, DC, USA, 1957; p. 579.

2. King, R.A. A Review of Soil Corrosiveness with Particular Reference to Reinforced Earth; TRRL Supplementary Report 316; Transport and Road Research Laboratory: Crowthorne, UK, 1977.

3. Gupta, S.K.; Gupta, B.K. The critical soil moisture content in the underground corrosion of mild steel. Corros. Sci. 1979, 19, 171-178. [CrossRef]

4. Levlin, E. Aeration cell corrosion of carbon steel in soil: In situ monitoring cell current and potential. Corros. Sci. 1996, 38, 2083. [CrossRef]

5. Ismail, A.I.M.; El-Shamy, A.M. Engineering behavior of soil materials on the corrosion of mild steel. Appl. Clay Sci. 2009, 42, 356-362. [CrossRef]

6. Cole, I.S.; Marney, D. The science of pipe corrosion: A review of the literature on the corrosion of ferrous metals in soils. Corros. Sci. 2012, 56, 5-16. [CrossRef]

7. Yan, M.; Sun, C.; Xu, J.; Dong, J.; Ke, W. Role of Fe oxides in corrosion of pipeline steel in a red clay soil. Corros. Sci. 2014, 80, 309-317. [CrossRef]

8. He, B.; Han, P.; Lu, C.; Bai, X. Effect of soil particle size on the corrosion behaviour of natural gas pipeline. Eng. Fail. Anal. 2015, 58, 19-30. [CrossRef]

9. Yan, M.; Sun, C.; Xu, J.; Ke, W. Electrochemical behaviour of API X80 steel in acidic soils from Southern East China. Int. J. Electrochem. Sci. 2015, 10, 1762-1776.

10. Akkouche, R.; Rémazeilles, C.; Jeannin, M.; Barbalat, M.; Sabot, R.; Refait, P. Influence of soil moisture on the corrosion processes of carbon steel in artificial soil: Active area and differential aeration cells. Electrochim. Acta 2016, 213, 698-708. [CrossRef]

11. Akkouche, R.; Rémazeilles, C.; Barbalat, M.; Sabot, R.; Jeannin, M.; Refait, P. Electrochemical monitoring of steel/soil interfaces during wet/dry cycles. J. Electrochem. Soc. 2017, 164, 626-634. [CrossRef]

12. Azoor, R.M.; Deo, R.N.; Birbilis, N.; Kodikar, J. On the optimum soil moisture for underground corrosion in different soil types. Corros. Sci. 2019, 159, 108116. [CrossRef]

13. Thomson, I.; Saithala, J.R. Review of pipeline coating systems from an operator's perspective. Corros. Eng. Sci. Technol. 2016, 51, 118-135. [CrossRef] 
14. NF EN 12954: 2019. General Principles of Cathodic Protection of Buried or Immersed Onshore Metallic Structures; AFNOR: La Plaine Saint-Denis, France, 2019.

15. NF EN ISO 15589-1: 2017. Petroleum, Petrochemical and Natural Gas Industries. Cathodic Protection of Pipeline Systems. Part 1: On-Land Pipelines; AFNOR: La Plaine Saint-Denis, France, 2017.

16. Humble, R.A. Cathodic protection of steel in seawater with magnesium anodes. Corrosion 1948, 4, 258-370. [CrossRef]

17. Wolfson, S.L.; Hartt, W.H. An initial investigation of calcareous deposits upon cathodic steel surfaces in seawater. Corrosion 1981, 37, 70-76. [CrossRef]

18. Barchiche, C.; Deslouis, C.; Festy, D.; Gil, O.; Refait, P.; Touzain, S.; Tribollet, B. Characterisation of calcareous deposits by electrochemical methods: Role of sulphates, calcium concentration and temperature. Electrochim. Acta 2004, 49, 2833-2839. [CrossRef]

19. Wang, K.; Varela, F.B.; Ta, M.Y. The effect of electrode surface area on corrosion initiation monitoring of X65 steel in soil. Corros. Sci. 2019, 152, 218-225. [CrossRef]

20. Leeds, S.S.; Cottis, R.A. An Investigation into the Influence of Surface Films on the Mechanism of Cathodic Protection; CORROSION/2006, Paper No. 06084; National Association of Corrosion Engineers: Houston, TX, USA, 2006.

21. Kodym, R.; Snita, D.; Fíla, V.; Bouzek, K.; Kouri, M. Investigation of processes occurring at cathodically protected underground installations: Experimental study of $\mathrm{pH}$ alteration and mathematical modeling of oxygen transport in soil. Corros. Sci. 2017, 120, 14-27. [CrossRef]

22. Kodym, R.; Snita, D.; Fíla, V.; Bouzek, K.; Kouri, M. Investigation of processes occurring at cathodically protected underground installations: Mathematical modeling of reaction-transport processes in soil. Corros. Sci. 2017, 120, 28-41. [CrossRef]

23. Barbalat, M.; Lanarde, L.; Caron, D.; Meyer, M.; Vittonato, J.; Castillon, F.; Fontaine, S.; Refait, P. Electrochemical determination of residual corrosion rates of steel under cathodic protection in soils. Corros. Sci. 2012, 55, 246-253. [CrossRef]

24. Barbalat, M.; Caron, D.; Lanarde, L.; Meyer, M.; Fontaine, S.; Castillon, F.; Vittonato, J.; Refait, P. Estimation of residual corrosion rates of steel under cathodic protection in soils via voltammetry. Corros. Sci. 2013, 73, 222-229. [CrossRef]

25. Nguyen, D.D.; Lanarde, L.; Jeannin, M.; Sabot, R.; Refait, P. Influence of soil moisture on the residual corrosion rates of buried carbon steel structures under cathodic protection. Electrochim. Acta 2015, 176, 1410-1419. [CrossRef]

26. Nguyen, D.D.; Jeannin, M.; Sabot, R.; Fleury, E.; Refait, P. On the use of voltammetry to estimate the efficiency of cathodic protection of buried steel structures. J. Mater. Eng. Perform. 2019, 28, 6042-6052.

27. Mahlobo, M.G.R.; Olubambi, P.A.; Jeannin, M.; Refait, P. Cathodic protection of buried steel structures: Processes occurring at the steel/soil interface during dry/wet cycles. Mater. Corros. 2020, 71, 451-463. [CrossRef]

28. Kossakowski, P.G. Prediction of ductile fracture for S235JR steel using the stress modified critical strain and Gurson-TvergaardNeedleman models. J. Mater. Civ. Eng. 2012, 24, 1492-1500. [CrossRef]

29. Rahal, C.; Masmoudi, M.; Abdelhedi, R.; Sabot, R.; Jeannin, M.; Bouaziz, M.; Refait, P. Olive leaf extract as a natural corrosion inhibitor for pure copper in $0.5 \mathrm{M} \mathrm{NaCl}$ solution: A study by voltammetry around OCP. J. Electroanal. Chem. 2016, 769, 53-61. [CrossRef]

30. Refait, P.; Jeannin, M.; Sabot, R.; Antony, H.; Pineau, S. Electrochemical formation and transformation of corrosion products on carbon steel under cathodic protection in seawater. Corros. Sci. 2013, 71, 32-36. [CrossRef]

31. Refait, P.; Jeannin, M.; Sabot, R.; Antony, H.; Pineau, S. Corrosion and cathodic protection of carbon steel in the tidal zone: Products, mechanisms and kinetics. Corros. Sci. 2015, 90, 375-382. [CrossRef]

32. Cherchilian, S.; Eichner, P.; Keddam, M.; Takenouti, H.; Mazille, H. A specific aspect of impedance measurements in low conductivity media. Artefacts and their interpretations. Electrochim. Acta 1990, 35, 1125.

33. Jiang, J.; Wang, J.; Hu, Y.; Lu, J.; Hu, Z. Effect of length of gas/liquid/solid three-phase boundary (TPB) zone on cathodic and corrosion behavior of metals. Electrochim. Acta. 2009, 54, 1426. [CrossRef]

34. Morcos, I. Double layer structure and the phenomena of wetting. J. Colloid Interface Sci. 1971, 37, 410. [CrossRef]

35. de Gennes, P.G. Wetting: Statics and dynamics. Rev. Mod. Phys. 1985, 57, 827. [CrossRef]

36. Jin-Hua, C.; Shi-Hui, S.; Li-Hua, N.; Shou-Zhuo, Y. A novel method for rapid determination of PZC for solid metal/solution interface. Electrochim. Acta 1997, 42, 689.

37. Sancy, M.; Gourbeyre, Y.; Sutter, E.M.M.; Tribollet, B. Mechanism of corrosion of cast iron covered by aged corrosion products: Application of electrochemical impedance spectrometry. Corros. Sci. 2010, 52, 1222-1227. [CrossRef]

38. Orazem, M.E.; Tribollet, B. Electrochemical Impedance Spectroscopy, 1st ed.; Wiley Interscience: New York, NY, USA, 2008.

39. Barcia, O.E.; D’Elia, E.; Frateur, I.; Mattos, O.R.; Pébère, N.; Tribollet, B. Application of the impedance model of de Levie for the characterization of porous electrodes. Electrochim. Acta 2002, 47, 2109-2116. [CrossRef]

40. Remita, E.; Boughrara, D.; Tribollet, B.; Vivier, V.; Sutter, E.; Ropital, F.; Kittel, J. Diffusion impedance in a thin-layer cell: Experimental and theoretical study on a large-disk electrode. J. Phys. Chem. C 2008, 112, 4626-4634. [CrossRef]

41. Bard, A.J.; Faulkner, L.R. Electrochemical Methods: Fundamentals and Application, 2nd ed.; Wiley: New York, NY, USA, 2001; p. 233.

42. Zhang, X.L.; Jiang, Z.H.; Yao, Z.P.; Song, Y.; Wu, Z.D. Effects of scan rate on the potentiodynamic polarization curve obtained to determine the Tafel slopes and corrosion current density. Corros. Sci. 2009, 51, 581-587. [CrossRef]

43. De Faria, D.L.A.; Silva, S.V.; Oliveira, M.T.D. Raman micro spectroscopy study of some iron oxides and oxyhydroxides. J. Raman Spectrosc. 1997, 28, 873-878. [CrossRef] 
44. Chicot, D.; Mendoza, J.; Zaoui, A.; Louis, G.; Lepingle, V.; Roudet, F.; Lesage, J. Mechanical properties of magnetite $\left(\mathrm{Fe}_{3} \mathrm{O}_{4}\right)$, hematite $\left(\alpha-\mathrm{Fe}_{2} \mathrm{O}_{3}\right)$ and goethite $(\alpha-\mathrm{FeO} \cdot \mathrm{OH})$ by instrumented indentation and molecular dynamics analysis. Mater. Chem. Phys. 2011, 129, 862-870. [CrossRef]

45. Zambrano, O.A.; Coronado, J.J.; Rodríguez, S.A. Mechanical properties and phases determination of low carbon steel oxide scales formed at $1200{ }^{\circ} \mathrm{C}$ in air. Surf. Coat. Technol. 2015, 282, 155-162. [CrossRef]

46. Da Costa, G.M.; De Grave, E.; De Bakker, P.M.A.; Venberghe, R.E. Influence of nonstoichiometry and the presence of maghemite on the Mössbauer spectrum of magnetite. Clays Clay Miner. 1995, 43, 656-668. [CrossRef]

47. Neff, D.; Bellot-Gurlet, L.; Dillmann, P.; Reguer, S.; Legrand, L. Raman imaging of ancient rust scales on archaeological iron artefacts for long-term atmospheric corrosion mechanisms study. J. Raman Spectrosc. 2006, 37, 1228-1237. [CrossRef]

48. Robineau, M.; Romaine, A.; Sabot, R.; Jeannin, M.; Deydier, V.; Necib, S.; Refait, P. Galvanic corrosion of carbon steel in anoxic conditions at $80^{\circ} \mathrm{C}$ associated with a heterogeneous magnetite $\left(\mathrm{Fe}_{3} \mathrm{O}_{4}\right) /$ mackinawite $(\mathrm{FeS})$ layer. Electrochim. Acta. 2017, 255, 274-285. [CrossRef]

49. Lopez Maldonado, K.L.; de la Presa, P.; de la Rubia, M.A.; Crespo, P.; de Frutos, J.; Hernando, A.; Matutes Aquino, J.A.; Elizalde Galindo, J.T. Effects of grain boundary width and crystallite size on conductivity and magnetic properties of magnetite nanoparticles. J. Nanoparticles Res. 2014, 16, 2482. [CrossRef] 